Provided for non-commercial research and education use. Not for reproduction, distribution or commercial use.

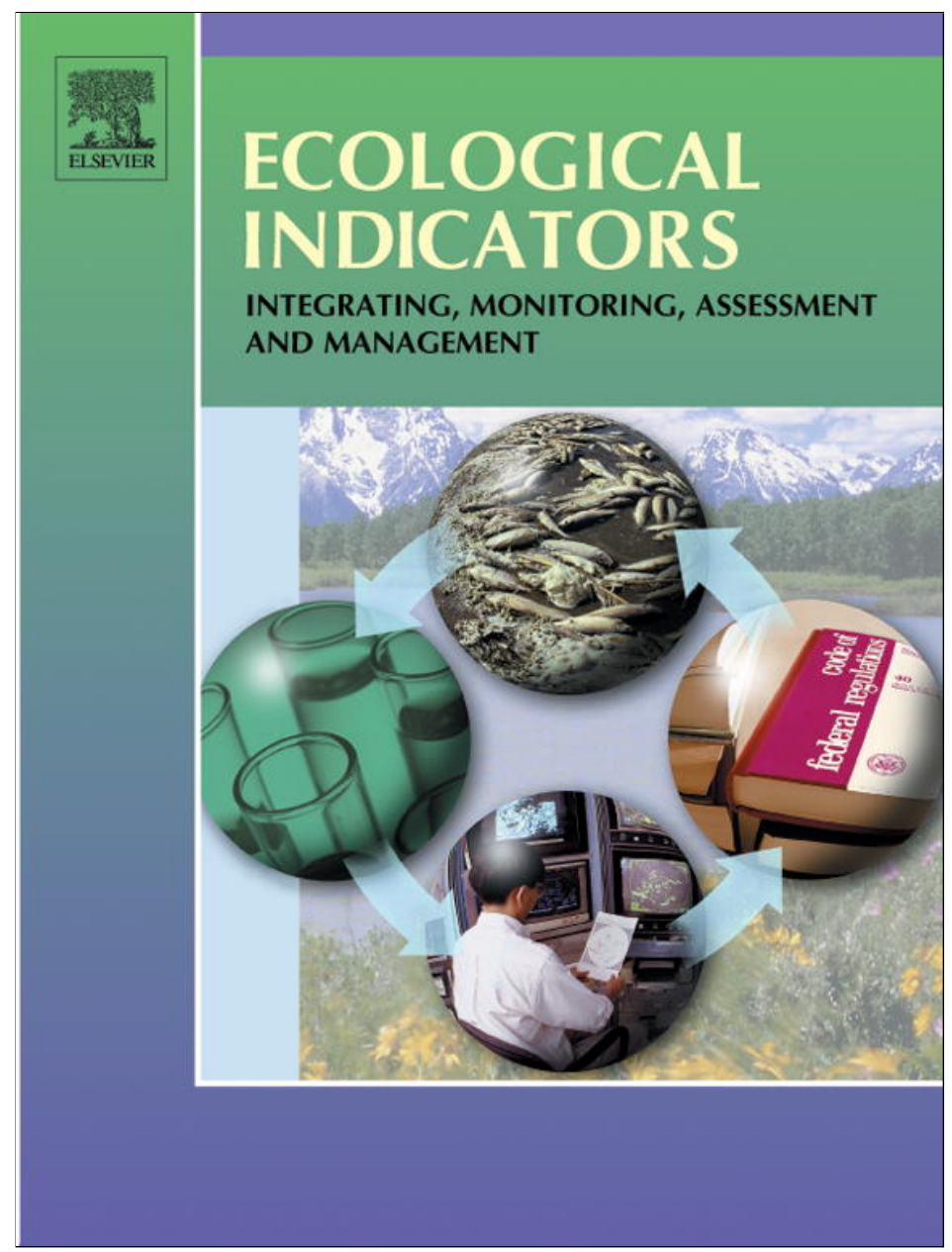

(This is a sample cover image for this issue. The actual cover is not yet available at this time.)

This article appeared in a journal published by Elsevier. The attached copy is furnished to the author for internal non-commercial research and education use, including for instruction at the authors institution and sharing with colleagues.

Other uses, including reproduction and distribution, or selling or licensing copies, or posting to personal, institutional or third party websites are prohibited.

In most cases authors are permitted to post their version of the article (e.g. in Word or Tex form) to their personal website or institutional repository. Authors requiring further information regarding Elsevier's archiving and manuscript policies are encouraged to visit:

http://www.elsevier.com/copyright 


\title{
Effects of natural hydrological variability on fish assemblages in small Mediterranean streams: Implications for ecological assessment
}

\author{
Paula Matono ${ }^{\mathrm{a}, \mathrm{b}, *}$, João M. Bernardo ${ }^{\mathrm{a}}$, Thierry Oberdorff ${ }^{\mathrm{c}}$, Maria Ilhéu ${ }^{\mathrm{a}, \mathrm{b}}$ \\ a Departamento de Paisagem, Ambiente e Ordenamento, Escola de Ciências e Tecnologia, Universidade de Évora, Rua Romão Ramalho 59, $7000-671$ Évora, Portugal \\ ${ }^{\mathrm{b}}$ Instituto de Ciências Agrárias e Ambientais Mediterrânicas (ICAAM), Universidade de Évora, Núcleo da Mitra, apartado 94, 7002-774 Évora, Portugal \\ ' UMR BOREA, IRD 207, Département Milieux et Peuplements Aquatiques, Muséum National d'Histoire Naturelle, 43 rue Cuvier, 75231 Paris cedex, France
}

\section{A R T I C L E I N F O}

\section{Article history:}

Received 26 December 2011

Received in revised form 22 April 2012

Accepted 22 April 2012

\section{Keywords:}

Intermittent streams

Natural disturbance

Human-induced degradation

Fish assemblages

Ecological assessment

Portugal

\begin{abstract}
A B S T R A C T
Small Mediterranean streams are shaped by predictable seasonal events of flooding and drying over an annual cycle, and present a strong inter and intra-annual variation in flow regime. Native fish assemblages in these streams are adapted to this natural environmental variability. The distinction of human-induced disturbances from the natural ones is thus a crucial step before assessing the ecological status of these streams. In this aim, the present study evaluates the effects of natural hydrological variability on fish assemblages from disturbed and least disturbed sites in small intermittent streams of south Portugal. Data were collected over the last two decades (1996-2011) in 14 sites located in the Guadiana and Sado river basins. High variability of fish assemblages was strongly dependent on human-induced disturbances, particularly nutrient/organic load and sediment load, and on natural hydrological variability. Natural hydrological variability can act jointly with anthropogenic disturbances, producing changes on fish assemblages structure of small intermittent streams. In least disturbed sites, despite the natural disturbances caused by inter-annual rainfall variations (including drought and flood events), fish assemblages maintained a long-term stability and revealed a high resilience. On the contrary, disturbed sites presented significantly higher variability on fish assemblages and a short and long-term instability, reflecting a decrease on the resistance and resilience of fish assemblages. Under these conditions, fish fauna integrity is particularly vulnerable and the ecological assessment may be influenced by natural hydrological variations. High hydrological variability (especially if it entails high frequency of dryer years and meaningful cumulative water deficit) may affect the impact of the human pressures with significant and consistent consequences on fish assemblage composition and integrity. In this study, fish metrics that maximize the detection of human degradation and minimize the response to natural variability were based on the relative abundance of native species (insectivorous species, eurytopic species, water column species, native lithophilic species), relative abundance of species with intermediate tolerance and relative number of exotic species. Results highlight the importance of assessing temporal variability on stream biomonitoring programs and emphasize the need to improve the assessment tools, accounting for long-term changes in fish assemblages, namely by selecting the most appropriate fish metrics that respond to anthropogenic disturbances but exhibit low natural temporal variability, essential both in the characterization of the biological reference conditions and in the development of fish indexes in intermittent streams.
\end{abstract}

(c) 2012 Published by Elsevier Ltd.

\section{Introduction}

Mediterranean streams and their endemic fish fauna are amongst the most threatened ecosystems and biota worldwide (Smith and Darwall, 2006; Hermoso and Clavero, 2011). The

* Corresponding author at: Departamento de Paisagem, Ambiente e Ordenamento, Escola de Ciências e Tecnologia, Universidade de Évora, Rua Romão Ramalho 59, 7000-671 Évora, Portugal. Tel.: +351 266745338; fax: +351 266745395.

E-mail address: pmatono@uevora.pt (P. Matono).
Mediterranean region is one of the areas in the world where landscapes have most experienced a simultaneous burst of human activities, such as intensive irrigated agriculture, extensive single cropping, tourism and urbanization. The southern regions (e.g. Portugal and Spain) are particularly vulnerable because of increasing water demands (Gasith and Resh, 1999; Laraus, 2004) and land use changes (e.g. Laraus, 2004; Peña et al., 2007; Symeonakis et al., 2007). In Portugal, besides water quality (e.g. organic and nutrients inputs) and morphological human induced pressures, the hydrological disturbance caused by large impoundments, like Alqueva reservoir in the Guadiana catchment, have considerable impacts 
on the native biota, namely fish fauna (Santos et al., 2004; Morais, 2008). Flow regulation and other modifications of flow regime and runoff decrease caused by damming and water abstraction are well known human induced hydrological pressures with major consequences in fish species abundance, structure and integrity (e.g. Gorman and Karr, 1978; Orth and Maughan, 1982; Freeman et al., 2001; Murchie et al., 2008; Benejam et al., 2009). Conversely, natural flow regimes are vital to the maintenance of a healthy biota in many river ecosystems (e.g. Poff et al., 1997; Lytle and Poff, 2004; Arthington et al., 2006).

Most rivers in Portugal are strongly influenced by the Mediterranean climate and the hydrological regime is strongly affected by precipitation both at intra and inter-annual scales. As a consequence, especially in southern regions, many rivers are temporary, exhibiting reduced or zero flow during the dry season. This intermittent character strongly shapes the environmental context to which the biota is subjected. The particular characteristics of the Mediterranean climate are also reflected in the irregular and unpredictable annual variation of river discharge. Many lowland Iberian and southern European rivers have huge inter and intra annual flow variations caused by irregular precipitation and frequent events of low flows related to dry periods.

High flows have been regarded as important natural processes maintaining a certain community structure and function in river systems (Cummins and Spengler, 1978; Resh et al., 1988). Many studies reported that an increase in stream flow lead to an increase in fish density and fish assemblage diversity (Pegg and Pierce, 2002; Aarts et al., 2004; Xenopoulos and Lodge, 2006). On the contrary, low flow conditions represent an important negative impact on fish assemblage structure (e.g. Gehrke et al., 1999; Pegg and Pierce, 2002; Sagawa et al., 2007) and some studies reported that reductions in flow result in impoverished fish assemblages often dominated by introduced species (Gehrke and Harris, 2001; Bernardo et al., 2003).

Small Mediterranean intermittent streams are particularly affected by hydrological variability, as available habitats, and their suitability to different life history stages, may fluctuate dramatically. Consequently, fish assemblages tend to present high temporal variability (Magalhães et al., 2002a; Bernardo et al., 2003; Clavero et al., 2005; Mesquita et al., 2006). Moreover, fish fauna exhibit relatively high resistance to harsh environmental conditions as these species evolved in a changeable and sometimes extreme environment (Almaça, 1995). Thus, fish assemblages may be resilient in the short-term to human pressure, whose influence can easily be misinterpreted, but eventually quite vulnerable on the long run to continuous and cumulative human-induced changes (Matthews and Marsh-Matthews, 2003).

The assessment of the ecological integrity in water bodies is a central issue to water policies and to nature conservation in general. In Europe, the implementation of the Water Framework Directive (WFD) (European Commission, 2000) requires the evaluation of ecological integrity of aquatic systems using biota. Accordingly, all Member States have to develop or adopt suitable biotic indexes and demonstrate they respond to human disturbances, i.e. to pressures, in an effective way. To attain this goal, it is important to discriminate between the effects of natural vs. human-induced environmental variability (Oberdorff et al., 2002; Pont et al., 2006).

In the context of Mediterranean rivers, a relevant issue is whether or not the natural environmental disturbance, particularly the hydrological one, can cause an undesirable bias, decreasing the ecological assessment accuracy in small Mediterranean streams. The crucial question is then Does the natural hydrological variability affect fish assemblages response to human pressure leading to less accurate assessment of the ecological status?

This paper presents data from least disturbed and disturbed sites during several years, evaluating the effects of hydrological

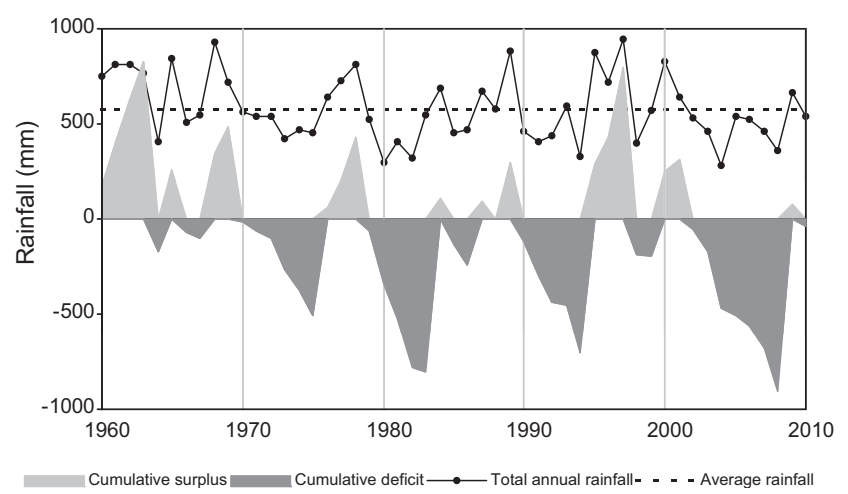

Fig. 1. Time series of total annual rainfall, cumulative rainfall surplus and deficit (deviations from the long-term average rainfall) between the hydrologic years of $1960 / 61$ and 2010/11 for a gauging station located in Degebe river (Guadiana basin). This pattern is roughly representative of the general rainfall pattern observed in all the gauging stations used, although absolute values may differ.

variability on fish assemblages structure and discussing its possible implications on streams ecological assessment. Specifically, the main objectives are: (i) to compare the effect of natural hydrological variability on fish assemblages in disturbed and least disturbed sites; (ii) to evaluate the relationship between hydrological variability and the impact of human-induced pressures; (iii) to identify fish metrics that maximize the detection of human induced degradation and minimize the response to natural variability.

\section{Methods}

\subsection{Study area}

Study sites were located in Guadiana and Sado river basins, two of the main rivers in the South of Portugal. This region is characterized by a Mediterranean climate, presenting high susceptibility to drought events (e.g. Pereira et al., 2006). The precipitation regime is highly irregular in the spatial and temporal domains, namely regarding the amount and distribution of rainfall (Daveau, 1977). Flow is strongly dependent on the seasonal distribution of rain, mainly concentrated in October-March. The hydrological regimes of sampled sites are very variable, with severe droughts and floods. These small streams are particularly affected during the summer dry season (June-September), when they are completely dry or reduced to isolated pools (in this case, over $50 \%$ of the streambed may dry up). Based on the existing hydrologic records for the South of Portugal, the inter-annual variation of discharge reaches a ratio of approximately 100-1 (ARHA, 2011).

During the last decades, severe drought events with a return period of 25-50 years occurred in 1994/95, 2004/05 and 2008/09 (Fig. 1). Other droughts were registered in 1991/92, 1992/93, $1998 / 99$ and $2003 / 04$, all with a return period of 10-25 years. Important events with above the average rainfall occurred in 1995/96-1997/98 and 2000/01. Over the last 50-year records, frequency and intensity of wetter and dryer periods (deviations from the long-term average rainfall) were quite similar. However, the duration of dry events was clearly higher, resulting in extended drought periods (cumulative deficit) (e.g. 1983/84, 1994/95, 2008/09). Therefore, in this study, sampling period (1996-2011) encompassed a wide range of hydrological conditions.

Owing to the relatively low mean annual precipitation (Fig. 1) and the constant increase on water demand for public supply and agriculture, numerous impoundments were built in this southern region: 67 in Sado catchment and 1643 in Guadiana catchment (ARHA, 2011). Other human impacts on rivers are mainly agriculture diffuse pollution and organic loading, channelization, sand 


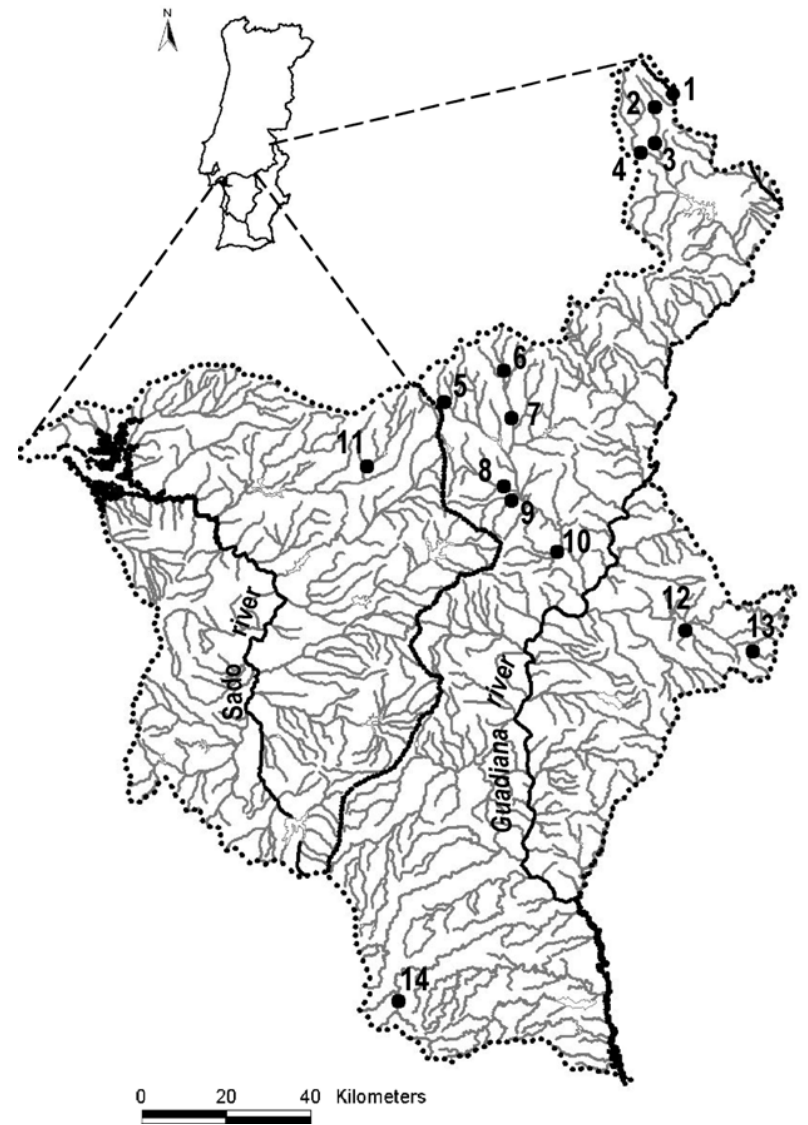

Fig. 2. Location of sampling sites in small southern Portuguese streams form Guadiana and Sado river basins: 1 - Cbx, 2 - Alg, 3 - Mos, 4 - Asm, 5 - Gar, 6 - Fqm, 7 Sdg, 8 - Azb, 9 - Pec, 10 - Ami, 11 - Val, 12 - Saf, 13 - Mtg, 14 - Vas.

extraction and water abstraction. All these factors have been responsible for major changes in aquatic ecosystems, threatening the native fish fauna.

Fish assemblages generally present low species richness and include many endemic species with high conservation status, particularly in Guadiana river (Cabral et al., 2005). In this basin, the most abundant and frequent species is roach (Squalius alburnoides Steindachner), followed by barbel species (Barbus microcephalus Almaça, Barbus comizo Steindachner, Barbus steindachneri Almaça) and Guadiana nase (Pseudochondrostoma willkommii Steindachner), all endemic species.

The Sado river basin is comparatively poorer, presenting high abundance of non-native species, namely pumpkinseed (Lepomis gibbosus L.). The most significant endemic species are roach ( $S$. alburnoides), common barbel (Barbus bocagei Steindachner), Iberian nase (Pseudochondrostoma polylepis Steindachner) and Portuguese nase (Iberochondrostoma lusitanicum Collares-Pereira).

\subsection{Sampling}

Data were collected in 14 least disturbed and disturbed sites located in southern Portuguese small intermittent streams (Fig. 2). Sites were sampled over a 4-11 years period between 1996 and 2011 , though not always in consecutive years. Site selection criteria privileged the availability of long-term data for each site, in order to allow significant temporal analysis. Only one site (Val) was located in the Sado river basin, being all the other sites located in the Guadiana river basin.

Sampling took place in early spring, following the protocol developed and adopted by the Portuguese Water Agency (INAG) for Portuguese rivers (INAG, 2008) under the implementation of the WFD, following also CEN protocol (CEN, 2003). Surveys were carried out always in flowing water conditions, immediately after the floods and previously to the strong reduction of flow during the summer period, in order to ensure high habitat diversity in the streams. At each site/year one stream section was sampled, encompassing all the existing physically homogeneous units (mesohabitats) - pool, run and riffle. The length of the sampled section was defined as 20 times the mean width of the stream, with a maximum of $150 \mathrm{~m}$ long. Fish were collected using backpack battery-powered electrofishing equipment (IG 200/2B, PDC Hans-Grassl GmbH, Schönau am Königssee, Germany), wading in shallow reaches $(<1.2 \mathrm{~m})$ or from a boat in deeper areas. Captured fishes were identified to the species level, measured and returned alive to the stream. The sampling method was maintained along the study sites/years, although the official protocols were only published in recent years. Indeed, the protocol developed under the WFD (INAG, 2008) incorporated exactly these sampling procedures and CEN (CEN, 2003).

Regional variables were obtained from digital cartography with free Internet access and included altitude of the site $(\mathrm{m})$, drainage area of the basin upstream of the site $\left(\mathrm{km}^{2}\right)$ and distance from source $(\mathrm{km})$. Local variables were assessed during the field sampling procedure: water temperature $\left({ }^{\circ} \mathrm{C}\right)$, conductivity $(\mu \mathrm{S} / \mathrm{cm})$, $\mathrm{pH}$, dissolved oxygen $(\mathrm{mg} / \mathrm{L})$, mean water depth $(\mathrm{m})$, mean current velocity $(\mathrm{m} / \mathrm{s})$ and dominant substrate class (adapted from Wentworth scale (Giller and Malmqvist, 1998): 1 - mud and sand; 2 gravel; 3 - pebble; 4 - cobble; 5 - boulders; 6 - boulders larger than $50 \mathrm{~cm}$ ).

In each sampling, human disturbance level was evaluated using 10 semi-quantitative variables (formerly developed within the EUproject FAME (2004), available at http://fame.boku.ac.at): land use, urban area, riparian vegetation, longitudinal connectivity of the river segment, sediment load, hydrological regime, morphological condition, presence of artificial lentic water bodies, toxicity and acidification levels, and nutrient/organic load. Each variable was scored from 1 (minimum disturbance) to 5 (maximum disturbance) (Table 1) and the sum of these scores represented the total human pressure in each site. Sites with scores 1 and/or 2 and only one variable with a 3 were considered least disturbed.

Several additional physicochemical parameters complemented and supported the evaluation of human-induced disturbance in each site (mainly organic/nutrient enrichment - Table 1) after laboratory measurements and analyses according to the Standard Methods for the Examination of Water and Wastewater (Clesceri et al., 1998): five day biological oxygen demand - BOD $_{5}$ $(\mathrm{mg} / \mathrm{L})$, chemical oxygen demand - COD $(\mathrm{mg} / \mathrm{L})$, phosphate $\mathrm{P}_{2} \mathrm{O}_{5}(\mathrm{mg} / \mathrm{L})$, total dissolved phosphorous - $\mathrm{P}(\mathrm{mg} / \mathrm{L})$, nitrite $\mathrm{NO}_{2}{ }^{-}(\mathrm{mg} / \mathrm{L})$, nitrate $-\mathrm{NO}_{3}{ }^{-}(\mathrm{mg} / \mathrm{L})$, ammonium $-\mathrm{NH}_{4}{ }^{+}(\mathrm{mg} / \mathrm{L})$ and total dissolved nitrogen - $\mathrm{N}(\mathrm{mg} / \mathrm{L})$. These parameters also reflect the water quality of the sampled sites, as their values interpretation was based on the water features for multiple uses, according to the Portuguese Water Agency guidelines (available at http://snirh.pt/snirh/_dadossintese/qualidadeanuario/boletim/ tabela_classes.php).

For samples prior to 2004, the human pressure variables were scored using all the information exhaustively gathered during sampling in all the sites (e.g. field records, photos, physicochemical parameters), and also from digital cartography and online information (e.g. SNIRH, available at http://snirh.pt).

\subsection{Data analysis}

In order to evaluate hydrological variability of sites, records from eleven gauging stations, geographically close to the sampling sites, were used (SNIRH, available at http://snirh.pt/). Rainfall was used 
Table 1

Description, assessment scale and methods, and scoring criteria of the 10 variables used to evaluate the level of anthropogenic disturbance in sampled sites.

\begin{tabular}{|c|c|c|c|c|c|}
\hline Variables & Description & Assessment scale & Score & Criteria & Methods \\
\hline \multirow[t]{10}{*}{ Land use } & \multirow[t]{5}{*}{$\begin{array}{l}\text { Impact of farming/forestry } \\
\text { practices }\end{array}$} & \multirow[t]{5}{*}{ River segment } & 5 & $\begin{array}{l}>40 \% \text { agricultural use (intensive agriculture), } \\
\text { very severe impact (rice field) }\end{array}$ & \multirow{10}{*}{$\begin{array}{l}\text { Local expert assessment } \\
\text { complemented with Corine } \\
\text { Land Cover }(2000,2006)^{\mathrm{a}}\end{array}$} \\
\hline & & & 4 & $\begin{array}{l}>40 \% \text { strong impact (area with strong forestry, } \\
\text { including clearcuts) }\end{array}$ & \\
\hline & & & 3 & $\begin{array}{l}<40 \% \text { moderate impact (subsistence gardens, } \\
\text { pastures) }\end{array}$ & \\
\hline & & & 2 & $\begin{array}{l}<40 \% \text { small impact (cork and holm oaks, } \\
\text { high-growth forest) }\end{array}$ & \\
\hline & & & 1 & $\begin{array}{l}<10 \% \text { no significant impacts (natural forest and } \\
\text { bush) }\end{array}$ & \\
\hline & \multirow{5}{*}{$\begin{array}{l}\text { Land cover and bankface } \\
\text { characterization }\end{array}$} & \multirow[t]{5}{*}{ Local } & 5 & Irrigated crops and/or high stocking & \\
\hline & & & 4 & Horticultural crops, semi-intensive grazing & \\
\hline & & & 3 & $\begin{array}{l}\text { Extensive cultures (e.g. pastures, cereal crops, } \\
\text { pine, eucalyptus), extensive grazing }\end{array}$ & \\
\hline & & & 2 & Cork and holm oaks & \\
\hline & & & 1 & Natural & \\
\hline \multirow[t]{5}{*}{ Urban area } & \multirow[t]{5}{*}{ Impact of urban areas } & \multirow[t]{5}{*}{ River segment } & 5 & $\begin{array}{l}\text { Very severe (location near a city with basic } \\
\text { sanitation needs) }\end{array}$ & \multirow{5}{*}{$\begin{array}{l}\text { Local expert assessment } \\
\text { complemented with Corine } \\
\text { Land Cover }(2000,2006)^{\mathrm{a}}\end{array}$} \\
\hline & & & 4 & Town & \\
\hline & & & 3 & Village & \\
\hline & & & 2 & Hamlet & \\
\hline & & & 1 & Negligible (isolated dwellings) & \\
\hline \multirow[t]{5}{*}{$\begin{array}{l}\text { Riparian } \\
\text { vegetation }\end{array}$} & \multirow[t]{5}{*}{$\begin{array}{l}\text { Deviation from the natural } \\
\text { state of the riparian zone }\end{array}$} & \multirow[t]{5}{*}{ River segment } & 5 & $\begin{array}{l}\text { Lack of riparian shrubs and trees (only the } \\
\text { presence of annual plants) }\end{array}$ & \multirow[t]{5}{*}{ Local expert assessment } \\
\hline & & & 4 & $\begin{array}{l}\text { Fragmented vegetation with bushes and/or the } \\
\text { presence of reed }\end{array}$ & \\
\hline & & & 3 & $\begin{array}{l}\text { Second replacement step (dominance of dense } \\
\text { brushwood) }\end{array}$ & \\
\hline & & & 2 & $\begin{array}{l}\text { First replacement step (presence of shrub or } \\
\text { tree strata with some level of preservation) }\end{array}$ & \\
\hline & & & 1 & $\begin{array}{l}\text { Potential vegetation (presence of shrub and } \\
\text { tree strata according to the geo-series) }\end{array}$ & \\
\hline \multirow[t]{5}{*}{$\begin{array}{l}\text { Morphological } \\
\text { condition }\end{array}$} & \multirow[t]{5}{*}{$\begin{array}{l}\text { Deviation from the natural } \\
\text { state of the stream bed and } \\
\text { banks }\end{array}$} & \multirow[t]{5}{*}{ Local } & 5 & $\begin{array}{l}\text { Transverse and longitudinal profile of the } \\
\text { channel completely changed, with very few } \\
\text { habitats }\end{array}$ & \multirow[t]{5}{*}{ Local expert assessment } \\
\hline & & & 4 & $\begin{array}{l}\text { Channelized sector, missing most of the } \\
\text { natural habitats }\end{array}$ & \\
\hline & & & 3 & $\begin{array}{l}\text { Channelized sector, missing some types of } \\
\text { natural habitats, but maintaining much of the } \\
\text { shape of the natural channel }\end{array}$ & \\
\hline & & & 2 & $\begin{array}{l}\text { Poorly changed sector, close to the natural } \\
\text { mosaic of habitats. }\end{array}$ & \\
\hline & & & 1 & Morphological changes absent or negligible & \\
\hline \multirow[t]{5}{*}{ Sediment load } & \multirow{5}{*}{$\begin{array}{l}\text { Deviation from the natural } \\
\text { sediment load (both carried in } \\
\text { the water column and } \\
\text { deposited on the riverbed) }\end{array}$} & \multirow[t]{5}{*}{$\begin{array}{l}\text { River segment } \\
\text { and local }\end{array}$} & 5 & $\begin{array}{l}>75 \% \text { of coarse particles of the stream bed are } \\
\text { covered with fine sediments (sand, silt, clay) }\end{array}$ & \multirow[t]{5}{*}{ Local expert assessment } \\
\hline & & & 4 & $\begin{array}{l}50-75 \% \text { of coarse particles of the stream bed } \\
\text { are covered with fine sediments (sand, silt, } \\
\text { clay) }\end{array}$ & \\
\hline & & & 3 & $\begin{array}{l}25-50 \% \text { of coarse particles of the stream bed } \\
\text { are covered with fine sediments (sand, silt, } \\
\text { clay) }\end{array}$ & \\
\hline & & & 2 & $\begin{array}{l}5-25 \% \text { of coarse particles of the bed are } \\
\text { covered with fine sediments (sand, silt, clay) }\end{array}$ & \\
\hline & & & 1 & $\begin{array}{l}<5 \% \text { of coarse particles of the stream bed are } \\
\text { covered with fine sediments (sand, silt, clay) }\end{array}$ & \\
\hline \multirow[t]{10}{*}{$\begin{array}{l}\text { Hydrological } \\
\text { regime }\end{array}$} & \multirow{10}{*}{$\begin{array}{l}\text { Deviation from the natural } \\
\text { hydrological regime (flow } \\
\text { pattern and/or quantity). } \\
\text { Includes all sources of } \\
\text { hydrologic alteration, such as } \\
\text { significant water abstraction }\end{array}$} & \multirow[t]{5}{*}{ Local } & 5 & $\begin{array}{l}<50 \% \text { and strong deviation from the natural } \\
\text { variability of the flow regime }\end{array}$ & $\begin{array}{l}\text { Local expert assessment } \\
\text { complemented with SNIRH }\end{array}$ \\
\hline & & & 4 & $\begin{array}{l}<50 \% \text { and moderate deviation from the natural } \\
\text { variability of the flow regime }\end{array}$ & \\
\hline & & & 3 & $\begin{array}{l}>50 \% \text { and duration of flood periods close to the } \\
\text { natural }\end{array}$ & \\
\hline & & & 2 & $\begin{array}{l}>75 \% \text { and duration of flood periods close to the } \\
\text { natural }\end{array}$ & \\
\hline & & & 1 & $\begin{array}{l}>90 \% \text { and normal duration of natural flood } \\
\text { periods }\end{array}$ & \\
\hline & & Local & 5 & $<10 \%$ of mean annual discharge & \\
\hline & & & 4 & $<15 \%$ of mean annual discharge & \\
\hline & & & 3 & $>15 \%$ of mean annual discharge & \\
\hline & & & 2 & $>30 \%$ of mean annual discharge & \\
\hline & & & 1 & $>90 \%$ of mean annual discharge & \\
\hline $\begin{array}{l}\text { Toxic and } \\
\text { acidification } \\
\text { levels }\end{array}$ & $\begin{array}{l}\text { Deviation from the natural } \\
\text { state of toxicity conditions, } \\
\text { including acidification and } \\
\text { oxygen levels }\end{array}$ & Local & 5 & $\begin{array}{l}\text { Constant for long periods (months) or frequent } \\
\text { occurrence of strong deviations from natural } \\
\text { conditions (e.g. } \mathrm{pH}<5.0 \text {, DO <30\%) }\end{array}$ & $\begin{array}{l}\text { Local expert assessment } \\
\text { complemented with SNIRH }\end{array}$ \\
\hline
\end{tabular}




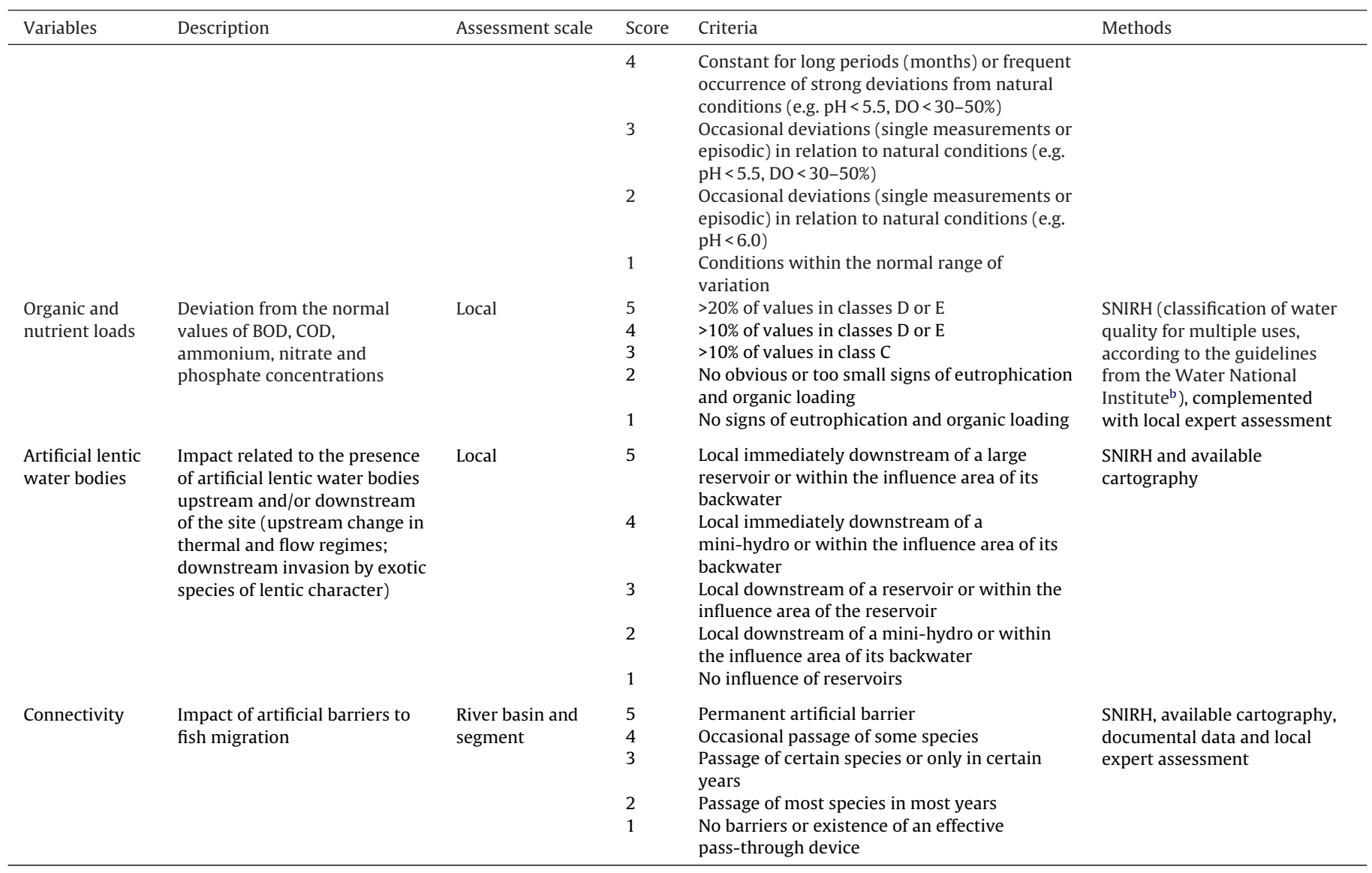

a Caetano et al. (2009).

b Information available at http://snirh.pt/snirh/_dadossintese/qualidadeanuario/boletim/tabela_classes.php.

instead of flow data because there were few gauging stations with long time series. Furthermore, as in small intermittent streams flow is more dependent on rainfall patterns than in any other streams, the use of rainfall data ensures a correct assessment of hydrological variability. Missing periods of records were filled using predictions of regression models. This procedure involved developing a linear equation to predict monthly rainfall for the missing period from nearby stations.

Using data from meteorological stations, and in situ measurements several variables were derived: mean total annual rainfall, coefficient of variation (CV - standard deviation/mean $\times 100)$ of total annual rainfall, relative frequency of dryer and wetter years, mean cumulative rainfall surplus and deficit, CV of mean water depth, CV of mean current velocity and CV of dominant substrate class. Variability of water depth, current velocity and dominant substrate were used as a measure of habitat modifications following hydrological disturbances, as these variables have already shown ecological relevance in fish assemblages patterns and distribution in most of the sampled streams (Ilhéu, 2004). Dryer and wetter years were identified based on annual rainfall deviations from the long-term average value (50-year records). Cumulative rainfall surplus and deficit were calculated using the theory of runs (Yevjevich, 1967). A run is defined as a portion of a time series of variable $x_{i}$, in which all values are either below or above a chosen critical level, $y_{c}$. Considering a discrete time series, $x_{1}, x_{2}, \ldots, x_{t}, \ldots, x_{n}$, a negative run occurs when $x_{t}$ is less than $y_{c}$ consecutively, during one or more time intervals. Negative runs in rainfall time series are related to drought characteristics and the difference between $y_{c}$ and $x_{t}$ is referred as deficit. Accordingly, positive runs are referred to as rainfall surplus. Cumulative values were then calculated as the run-sums of consecutive negative (deficit) or positive (surplus) deviations from the long-term average rainfall, with changes in the signal of deviations reset to zero. These cumulative values were standardized by the total annual rainfall in each site, to allow comparisons between sites.

Individual human pressure variables and total pressure were averaged for each site. The increase in human pressure along the study period was also quantified for each site, calculating the difference in total pressure between the first and the last sampling occasions. According to the increase in human disturbance level, some sites changed their classification from least disturbed to disturbed during the study period. In these cases, sites were analysed according to their classification, depending on the sampling occasion.

Fish captures were standardized to an area of $100 \mathrm{~m}^{2}$ in all samples and expressed as density (number of fish $/ 100 \mathrm{~m}^{2}$ ). The study period was long enough to encompass at least one mean generation time for all the species captured, thus allowing meaningful judgments concerning patterns of fish assemblage variability (Grossman et al., 1990).

Different approaches were used to access variability in fish assemblages composition over time:

(i) Assemblage persistence $(P)$ describes the repeated extinction and immigration of populations in ecological assemblages (Oberdorff et al., 2001) and was quantified as $(P=1-T)$ where $T$ is the species turnover rate. Following Eby et al. (2003), Magalhães et al. (2007) and Oberdorff et al. (2001), turnover rate was defined as $T=(C+E) /\left(S_{1}+S_{2}\right)$, where $C$ and $E$ are the number of species that colonized or were extirpated between 
two sampling occasions and $S_{1}$ and $S_{2}$ are the number of species present in each occasion. $T$ ranges from 0 (no turnover) to 1 (complete turnover), so persistence ranges from 0 (no persistence) to 1 (complete persistence). For each site, sequential $P$ values along the sampled years were averaged.

(ii) Stability of fish assemblages composition considering species relative abundance was quantified with Bray-Curtis similarity coefficient (Clarke and Warwick, 1994) between each possible pair of sampled years in each site. Mean similarity was subsequently calculated for each site.

(iii) Nonmetric Multidimensional Scaling (MDS) (Clarke and Warwick, 1994) of samples, based on the Bray-Curtis similarity matrices calculated in (ii) for each site with the temporal trajectory overlaid. The displacement pattern of points in the plots allowed identifying changes in fish assemblages along the years (Clarke and Warwick, 1994). Fish assemblages could show changes followed by a return to an earlier state (indicating a cyclic pattern of variability with no long-term directional shift) or progressive displacements further away from the original position (indicating a directional shift in composition).

(iv) Time lag regression analysis (see Collins, 2000; Eby et al., 2003; Magalhães et al., 2007) complemented the MDS and was used to examine whether fish assemblages were undergoing a long-term directional change (linear regression). The method involves the calculation of the Euclidean Distance (ED) between each possible pair of annual samples. Regression models where then conducted between ED and the square root of the time lag separating the samples. The square root transformation reduces possible bias in the analysis resulting from few data points at larger time lags.

Possible changes in ecological integrity of fish assemblages along the study period in each site were evaluated through variability in structural and functional features of fish assemblages. These community attributes, or fish metrics, included fish density, species richness and diversity (Shannon-Wiener Index), relative abundance of non-native, potamodromous and long lived species and functional guilds related to habitat (relative abundance of rheophilic, limnophilic, eurytopic, benthic and water column species), breeding (relative abundance of lithophilic and phytophilic species), feeding (relative abundance of omnivorous and insectivorous species) and tolerance (relative abundance of intolerant, tolerant and intermediate tolerance species) to which captured species were assigned according to published literature (FAME, 2004; Ilhéu, 2004; Cabral et al., 2005; Holzer, 2008; Magalhães et al., 2008) and expert judgment based on the available knowledge.

A total of 117 metrics was initially considered for analysis, expressed in abundance and number of species, in relative and absolute terms and calculated for total fish assemblages and for native species assemblages. Individual fish metrics were then screened for natural variability by calculating their CV in least disturbed and disturbed sites, and for their response to anthropogenic disturbances using Spearman rank correlation coefficient $(|r| \geq 0.5$; $P<0.05)$ between fish metrics and human pressure variables. Mann-Whitney test was used to detect significant differences in fish metrics CVs between least disturbed and disturbed sites (Siegel and Castellan, 1988). Only non-redundant metrics, presenting significantly low natural variability $(\mathrm{CV}<50 \%)$ (Grossman et al., 1990) under least disturbed conditions over time compared to disturbed sites, and significant responses to human pressure variables were selected. As for assemblages composition, variability in fish metrics was quantified with Bray-Curtis similarity coefficients for each site.

Relationships between fish assemblages variability, human disturbances and hydrological variability were assessed with Spearman rank correlation coefficient $(|r| \geq 0.5 ; P<0.05)$ and using Redundancy Analysis (RDA) (Jongman et al., 1987). The model was tested with Monte Carlo test (999 permutations). Correlations larger than $|0.4|$ were used in gradients interpretation. To account for multicollinearity, variables were maintained in the models only if their addition did not cause any Variation Inflation Factor (VIF) exceeding 3. A linear ordination method was selected as a preliminary Detrended Correspondence Analysis has shown a gradient length smaller than 3SD (ter Braak and Smilauer, 1998). The possible influence of species richness, total fish density and landscape gradients in fish assemblages variability was taken into account in these analyses.

For sequential Spearman rank correlations and Mann-Whitney tests the obtained $P$-values were adjusted using the Bonferroni correction (see Wright, 1992) and the significance level was set at 0.05 .

All data were either $\log (x+1)$ (linear measurements) or arc$\sin [\operatorname{sqrt}(x)]$ (percentages) transformed (Legendre and Legendre, 1998) before calculating Bray-Curtis similarities and performing MDS, Spearman rank correlations and RDA. Statistical analyses were performed using the software Statistica 6.0 (StatSoft Inc., 2001), Primer 6.0 (Clarke and Gorley, 2006) and Canoco 4.5 (ter Braak and Smilauer, 2002).

\section{Results}

\subsection{Environmental and anthropogenic characterization of sites}

Sampled streams are representative of small southern Portuguese streams, showing a strong intermittent character. Table 2 summarizes the environmental and anthropogenic characterization of sampled sites considering the period and years of sampling.

Drainage area of streams ranged between $10.2 \mathrm{~km}^{2}$ and $192.9 \mathrm{~km}^{2}$. Alg, Asm, Cbx, Fqm, Gar and Mos, with drainage areas lower than $60 \mathrm{~km}^{2}$, represented the smallest streams. Mtg, Ami, Pec, Saf and Vas have drainage areas around $100 \mathrm{~km}^{2}$. Finally, Azb, Sdg and Val presented the larger drainage areas, with values between $150 \mathrm{~km}^{2}$ and $200 \mathrm{~km}^{2}$. Distance from source was highly correlated with drainage area and was therefore excluded from the analyses. As expected, altitude of sites showed a negative relation with drainage area $(r=-0.74 ; P<0.01)$, with Alg, Cbx and Mos located in the highest altitudes, followed by Asm and Vas. Lowest altitudes were registered for Saf and Val.

Considering the hydrological variables, annual rainfall was strongly correlated with altitude $(r=0.71$; adj $P<0.01)$, with particularly high values occurring in Alg and Cbx (higher than $900 \mathrm{~mm}$ ). Asm and Vas showed slightly lower values (around 700 and $800 \mathrm{~mm}$ ) and Saf registered the lowest annual rainfall. In all the other sites values ranged somewhere between $500 \mathrm{~mm}$ and $600 \mathrm{~mm}$ rainfall. Cumulative rainfall surplus was also correlated with altitude $(r=0.64$; adj $P<0.05)$ and cumulative rainfall deficit was related to the relative frequency of dryer years $(r=0.79$; adj $P<0.01)$ and wetter years $(r=-0.79$; adj $P<0.01)$ and maximum values were observed in $\mathrm{Cbx}$, Fqm, Sdg and Vas. Overall hydrological variability, i.e. CV of annual rainfall was highest in Gar (>50\%), followed by Fqm, Mos, Azb, Pec, Sdg and Val (between 30\% and $50 \%)$. The lowest hydrological variability was observed in Mtg and Vas $(<20 \%)$.

Regarding local variables, current velocity showed high variability in general and water depth presented a moderate variability in most sites. Sites with thinner substrate tended to show higher substrate variability over time (e.g. Azb and Ami) than sites with coarser substrate (e.g. Val and Vas).

During the sampling years, almost all sites registered an increase in human pressure, except Val. Accordingly, most of the least disturbed sites have changed their abiotic classification along the years (Asm, Fqm, Mtg, Ami, Azb). All these sites suffered a marked 


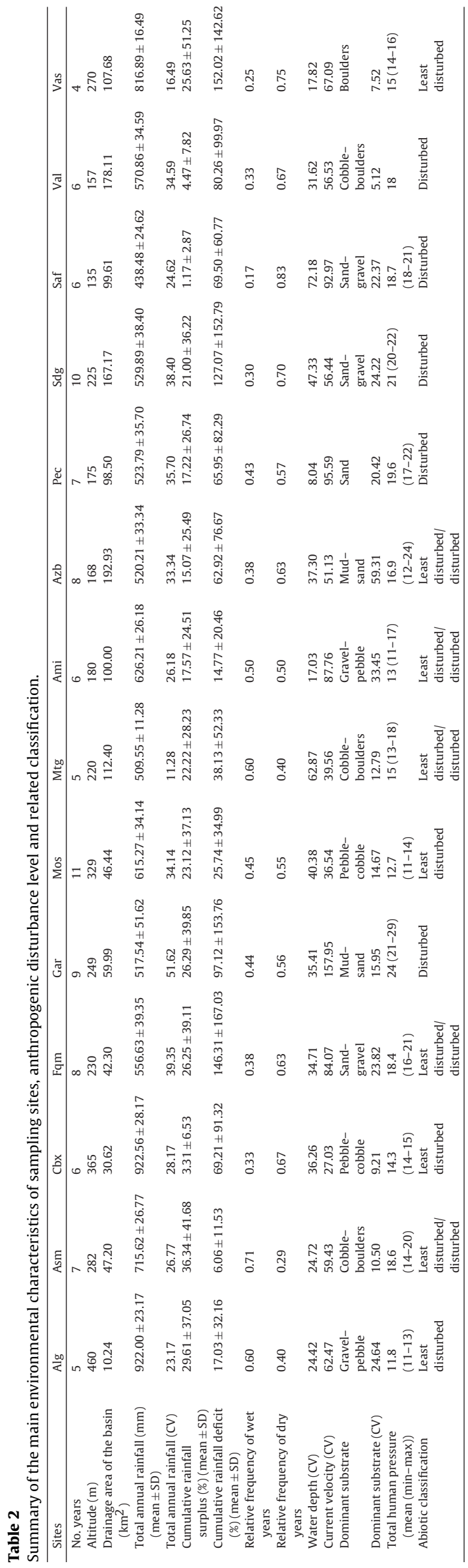

increase in human pressure and two even became some of the most disturbed ones (Azb and Fqm). Only Alg, Cbx, Mos and Vas remained least disturbed. As these sites are located at high altitudes, a negative correlation between total pressure and altitude of sites was observed $(r=-0.5$; adj $P<0.05)$. On the contrary, Gar, Pec, Sdg and Saf were always subjected to meaningful anthropogenic disturbances, which continued to increase along the years, especially in Gar.

Total human pressure and its increase were mainly due to land use/land use changes $(r=0.78$; adj $P<0.01)$, namely throughout agriculture and livestock intensification in the last years, degradation of riparian vegetation $(r=0.94$; adj $P<0.001)$, nutrient/organic input $(r=0.74$; adj $P<0.05)$ and sediment load $(r=0.85$; adj $P<0.001)$. Considering that these variables were all significantly intercorrelated $(r>0.5$; adj $P<0.01)$, riparian degradation may occur independently or as a consequence of land use practices, leading all together to increases in nutrient/organic input and sediment loads in sampled streams. The remaining pressure variables were fairly stable and ranged mostly between high (score 1) and good (score 2) condition.

\subsection{Composition, persistence and stability of fish assemblages}

Eleven native species and eight non-native species were captured during the study (Table 3 ). S. alburnoides was the most abundant and frequent species in most of the sites. Squalius pyrenaicus was particularly abundant and frequent in Alg, Cbx and Vas. Iberochondrostoma lemmingii and Cobitis paludica tended to occur in sites with finer substrate, especially in Fqm, Gar and Saf, which were also some of the most human disturbed sites. Nevertheless, C. paludica also occurred with high relative abundance in Asm, Mos and Vas. Barbels were all widespread species, though higher abundances and frequencies of occurrence were observed for $B$. microcephalus and juvenile individuals (Barbus spp.). B. bocagei only occurred in Val, the only site sampled in the Sado river basin, due to different and restricted distribution areas of barbel species. $P$. willkommii showed higher occurrence and abundance in Mos, Ami and $\mathrm{Cbx}$. The occurrence of Anaecypris hispanica, a small endemic and endangered species was reduced to three sites and only showed meaningful values in Asm. Overall, fish assemblages were dominated by native species in the least disturbed sites. Non-native species were mainly present in human disturbed sites, particularly in Gar, Pec, Sdg, Saf and Val, where they represented a large percentage of the total fish species or even dominated the assemblages. Non-natives were mostly represented by L. gibbosus and Gambusia holbrooki.

Total number of fish species within sites ranged from 2 to 9 , with lower mean values occurring in Alg and Val. In the remaining sites, mean species richness was very similar. As such, this metric was fairly stable along the years in least disturbed sites (mean $\mathrm{CV}=21.8 \%$ ) and moderately stable in disturbed ones (mean $\mathrm{CV}=40.4 \%$ ). Fish density showed high variability amongst sampled sites (mean CV between $61 \%$ and $188 \%$ ) with no significant differences between disturbed and least disturbed sites (adj $P>0.05$ ) (Table 4).

Persistence and stability of fish assemblages composition followed a similar pattern in sampled sites $(r=0.57 ; P<0.05)$, yet persistence values were less variable than stability between sites. Persistence registered the highest values in Alg, Vas and Cbx, and the lowest in Fqm and Mtg. Assemblage stability was highest in $\mathrm{Alg}$ and $\mathrm{Cbx}$, and lowest in Fqm and Pec. Neither persistence nor variability in fish assemblages composition revealed significant correlations (adj $P>0.05$ ) with species richness or with total fish density (Table 4).

Multidimensional Scaling and time lag regression analysis provided complementary results, showing different trends in fish 
Table 3

List of captured species (scientific and common names), occurrence type (End Ib - Iberian endemism; End Bas - Basin endemism) in Guadiana and/or Sado river basins and respective frequency of occurrence.

\begin{tabular}{|c|c|c|c|c|c|}
\hline \multirow[t]{2}{*}{ Species } & \multirow[t]{2}{*}{ Common name } & \multicolumn{4}{|c|}{ Occurrence } \\
\hline & & Type & Guadiana basin & Sado basin & Frequency \\
\hline Anaecypris hispanica & Spanish Minnow Carp & End Bas & $\mathrm{x}$ & & 0.05 \\
\hline Barbus spp. (juveniles) & juvenile Barbels & End Ib & $\mathrm{x}$ & & 0.52 \\
\hline Barbus bocagei & Common Barbel & End Ib & & $\mathrm{x}$ & 0.05 \\
\hline Barbus steindachneri & Steindachner Barbel & End $\mathrm{Ib}$ & $\mathrm{x}$ & & 0.12 \\
\hline Barbus comizo & Iberian Gudgeon & End $\mathrm{Ib}$ & $\mathrm{x}$ & & 0.17 \\
\hline Barbus sclateri & South Barbel & End Ib & $\mathrm{x}$ & & 0.02 \\
\hline Barbus microcephalus & Small-head Barbel & End Bas & $\mathrm{x}$ & & 0.52 \\
\hline Squalius pyrenaicus & Iberian Chub & End Ib & $\mathrm{x}$ & $\mathrm{x}$ & 0.51 \\
\hline Squalius alburnoides & Roach & End Ib & $\mathrm{x}$ & $\mathrm{x}$ & 0.86 \\
\hline Pseudochondrostoma willkommii & Guadiana Nase & End Ib & $\mathrm{x}$ & & 0.38 \\
\hline Iberochondrostoma lemmingii & Arched-mouth Nase & End Ib & $\mathrm{x}$ & & 0.41 \\
\hline Cobitis paludica & South Stone Loach & End $\mathrm{Ib}$ & $\mathrm{x}$ & $\mathrm{x}$ & 0.58 \\
\hline Lepomis gibbosus & Pumpkinseed & Nnat & $\mathrm{x}$ & $\mathrm{x}$ & 0.57 \\
\hline Cyprinus carpio & Common Carp & Nnat & $\mathrm{x}$ & $\mathrm{x}$ & 0.11 \\
\hline Carassius auratus & Goldfish & Nnat & $\mathrm{x}$ & $\mathrm{x}$ & 0.01 \\
\hline Micropterus salmoides & Largemouth Bass & Nnat & $\mathrm{x}$ & $\mathrm{x}$ & 0.08 \\
\hline Herichtys facetum & Chamaleon Cichlid & Nnat & $\mathrm{x}$ & $\mathrm{x}$ & 0.01 \\
\hline Ameiurus melas & Black Bullhead & Nnat & $\mathrm{x}$ & $\mathrm{x}$ & 0.02 \\
\hline Alburnus alburnus & Bleak & Nnat & $\mathrm{x}$ & $\mathrm{x}$ & 0.08 \\
\hline Gambusia holbrooki & Mosquitofish & Nnat & $\mathrm{x}$ & $\mathrm{x}$ & 0.32 \\
\hline
\end{tabular}

Table 4

Species richness (mean; min-max), fish density (ind/100 $\left.\mathrm{m}^{2}\right)$ (mean $\pm \mathrm{SD}$ ), assemblage persistence $(P)$ and stability (mean Bray-Curtis similarity coefficient) in each site.

\begin{tabular}{|c|c|c|c|c|}
\hline Sites & $\begin{array}{l}\text { Species richness } \\
(\text { mean }(\text { min-max }))\end{array}$ & $\begin{array}{l}\left.\text { Fish density (ind } / 100 \mathrm{~m}^{2}\right) \\
(\text { mean } \pm S D)\end{array}$ & $\begin{array}{l}\text { Assemblage } \\
\text { persistence }(P)\end{array}$ & $\begin{array}{l}\text { Assemblage stability } \\
\text { (mean similarity) }\end{array}$ \\
\hline Alg & 2 & $68.85 \pm 129.45$ & 1 & 93.4 \\
\hline Asm & $6(3-9)$ & $100.78 \pm 96.05$ & 0.75 & 66.00 \\
\hline Cbx & $4.8(3-6)$ & $129.20 \pm 100.97$ & 0.80 & 81.40 \\
\hline Fqm & $4.6(1-7)$ & $16.84 \pm 13.95$ & 0.44 & 60.00 \\
\hline Gar & $5.1(4-7)$ & $60.36 \pm 50.99$ & 0.83 & 71.00 \\
\hline Mos & $4.7(3-6)$ & $87.34 \pm 118.04$ & 0.72 & 75.60 \\
\hline Mtg & $3.8(1-9)$ & $9.80 \pm 13.17$ & 0.46 & 71.60 \\
\hline Ami & $5.3(4-7)$ & $24.18 \pm 14.82$ & 0.70 & 64.30 \\
\hline Azb & $5.1(4-8)$ & $64.04 \pm 106.62$ & 0.61 & 65.10 \\
\hline Pec & $5.2(3-8)$ & $43.16 \pm 50.64$ & 0.63 & 57.90 \\
\hline Sdg & $6.8(3-9)$ & $28.74 \pm 20.16$ & 0.73 & 63.60 \\
\hline Saf & $5.3(4-7)$ & $71.80 \pm 65.94$ & 0.60 & 60.90 \\
\hline Val & $3(2-5)$ & $11.69 \pm 11.22$ & 0.54 & 72.40 \\
\hline Vas & $5.8(5-6)$ & $20.35 \pm 31.26$ & 0.88 & 77.60 \\
\hline
\end{tabular}

assemblages variability for sampling sites (Table 5, Figs. 3 and 4). Fqm, Gar, Ami, Azb, Pec, Sdg, Saf and Val showed significant linear patterns of changes in fish assemblages considering both MDS and time lag regression results. Despite the low values obtained for the determination coefficient $\left(R^{2}\right)$ in several sites, particularly in Fqm and Azb, the regression models and all the equations coefficients

Table 5

Results from Multidimensional Scaling (MDS) and time lag regression analysis in each site.

\begin{tabular}{|c|c|c|c|}
\hline \multirow[t]{2}{*}{ Sites } & \multicolumn{2}{|c|}{ Time lag regression (linear) } & \multirow{2}{*}{$\begin{array}{l}\text { MDS } \\
\text { Trajectory }\end{array}$} \\
\hline & $R^{2}$ & Trend & \\
\hline Alg & n.s. & - & Cyclic \\
\hline Asm & n.s. & - & Random \\
\hline Cbx & n.s. & - & Cyclic \\
\hline Fqm & $0.10 ; P<0.05$ & Directional & Directional \\
\hline Gar & $0.24 ; P<0.01$ & Directional & Directional \\
\hline Mos & n.s. & - & Cyclic \\
\hline Mtg & n.s. & - & Random \\
\hline Ami & $0.52 ; P<0.01$ & Directional & Directional \\
\hline Azb & $0.17 ; P<0.05$ & Directional & Directional \\
\hline Pec & $0.29 ; P<0.01$ & Directional & Directional \\
\hline Sdg & $0.23 ; P<0.001$ & Directional & Directional \\
\hline Saf & $0.29 ; P<0.05$ & Directional & Directional \\
\hline Val & $0.31 ; P<0.05$ & Directional & Directional \\
\hline Vas & n.s. & - & Cyclic \\
\hline
\end{tabular}

were significant, confirming the existence of a linear pattern underlying the data. Alg, Cbx, Mos and Vas did not show significant results for time lag regression, but MDS plots revealed the existence of cyclic patterns in fish assemblages. For Asm and Mtg results suggest a random pattern, with no evident trend in fish assemblages changes. Overall, results suggest a trend away from cyclic patterns towards linear patterns with the increase in total human pressure.

\subsection{Structural and functional changes in fish assemblages}

The mean CVs of fish metrics expressed in terms of absolute abundance were extremely high (>100\%). On the contrary, fish metrics based on relative abundance, absolute and relative number of species revealed lower variability, particularly in undisturbed sites (<50\%). 32 fish metrics with low temporal variability revealed significant differences between least disturbed and disturbed sites. After further screening for significant responses to human pressure variables, seven metrics were selected to evaluate possible ecological changes in fish assemblages (Table 6): relative abundance of native species, relative abundance of native insectivorous species, relative abundance of native eurytopic species, relative abundance of native water column species, relative abundance of native lithophilic species, relative abundance of species with intermediate tolerance and relative number of non-native species. Despite the observed redundancy between metrics calculated for 
Table 6

Fish metrics selected to evaluate structural and functional variability of fish assemblages in sites. Differences in the coefficients of variation (mean \pm SD) between least disturbed and disturbed sites are significant at $P<0.001$, and significant correlations $(|r| \geq 0.5$; adj $P<0.05)$ with human pressure variables are listed.

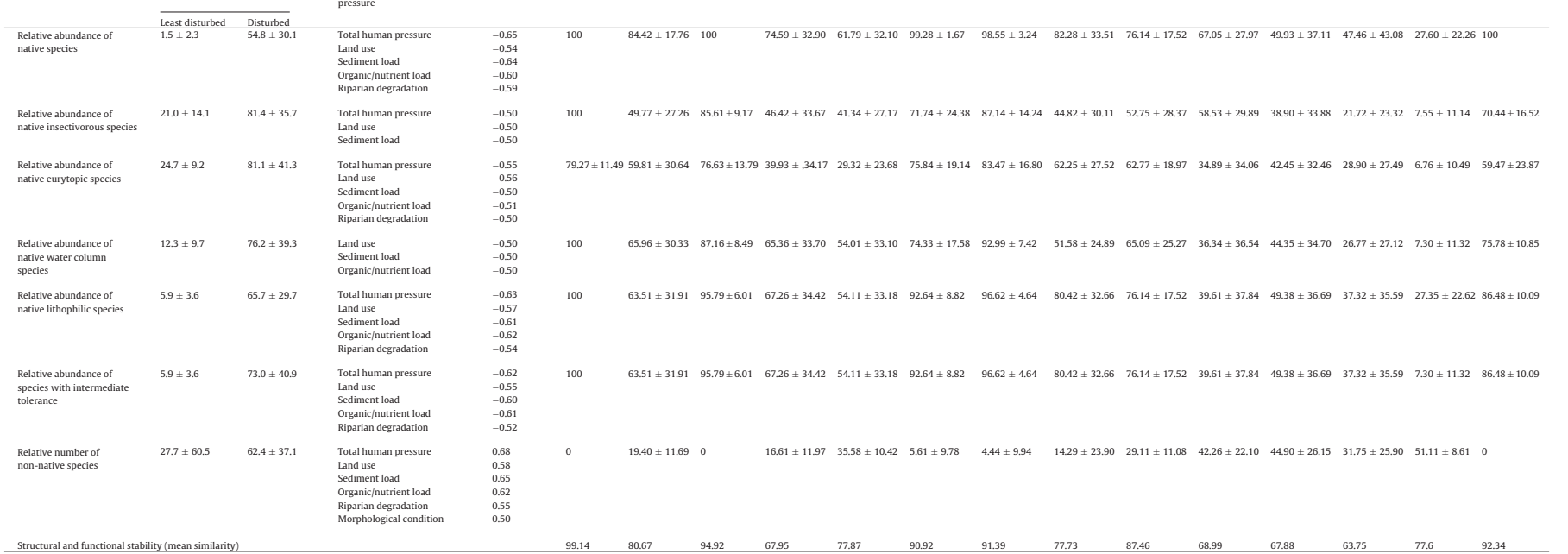




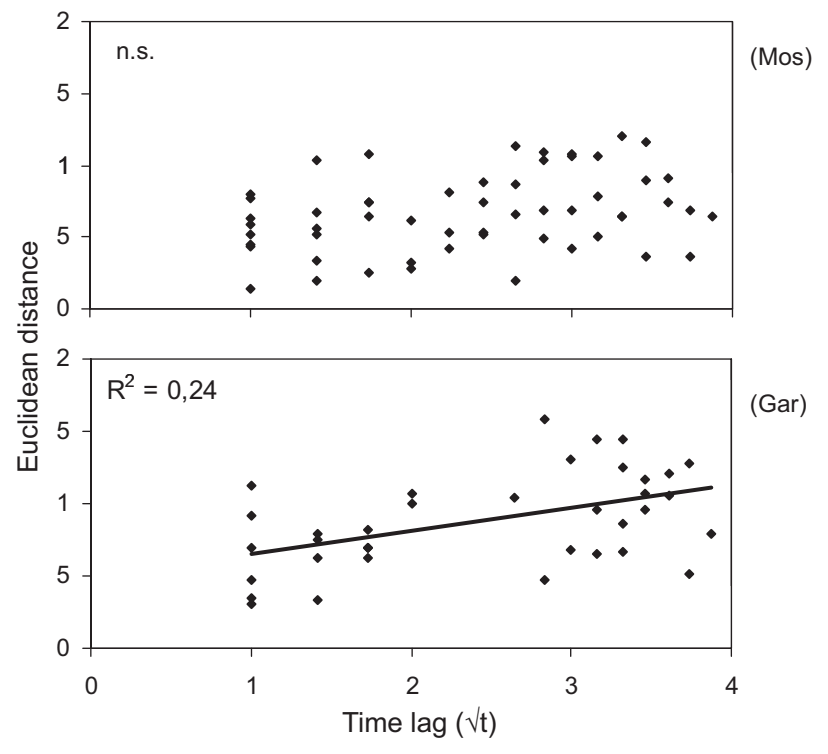

Fig. 3. Time lag regression analysis for sampled sites Mos and Gar, showing examples of absent and directional (linear regression) trends in fish assemblages over the study period.
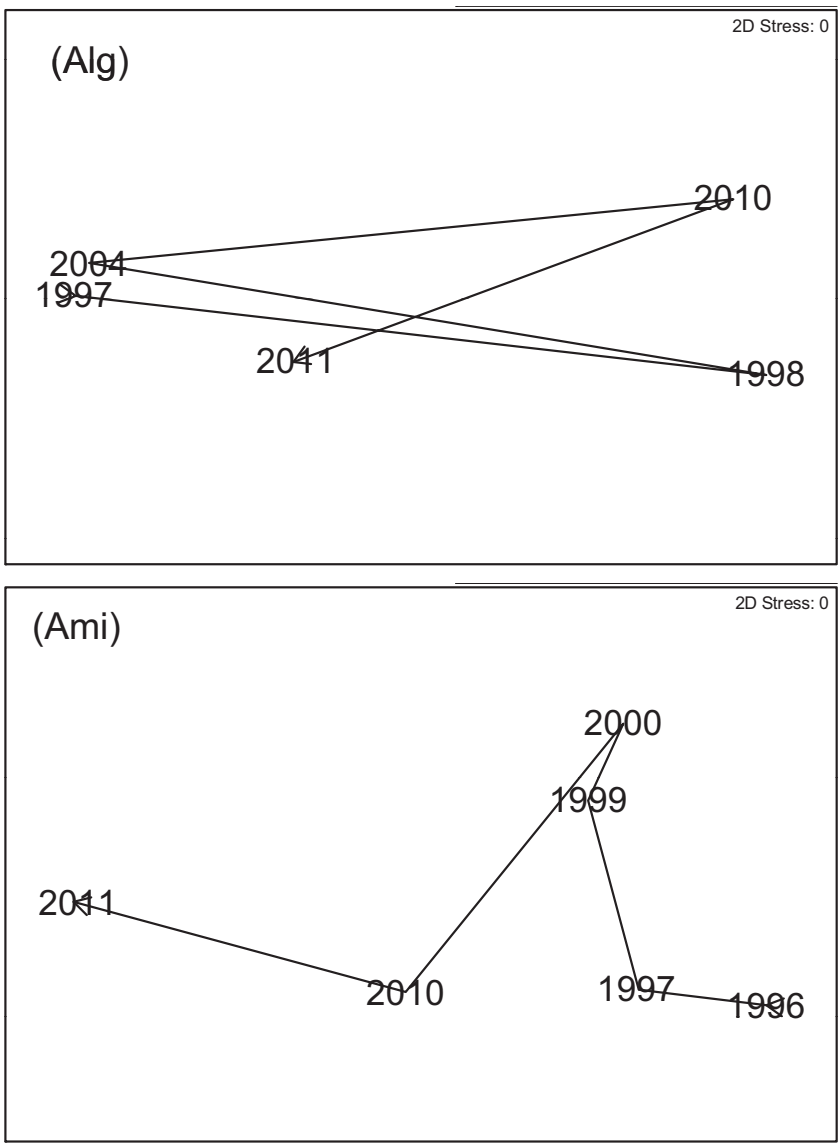

Fig. 4. 2-dimensional MDS configuration plots for sampled sites Alg and Ami with superimposed temporal trajectory, showing examples of directional (progressive move further away from the initial position) and cyclic (displacement followed by a return to an earlier position) changes in fish assemblages over the study period. The stress values obtained $(<0.05)$ indicate an excellent ordination diagram, with no prospect of misinterpretation (Clarke and Warwick, 1994). total fish assemblages and for native assemblages, native metrics behaved better, regarding the selection criteria.

All the selected metrics showed significant correlations $(|r|>0.5$; $\operatorname{adj} P<0.001$ ) mainly with total human pressure, sediment load and organic/nutrient enrichment, although meaningful relations were also observed with land use, degradation of riparian vegetation, and morphological condition (Table 6). The non-native metric was positively related with human pressure variables, whereas the native metrics showed and inverse response.

Mean values of fish metrics in each site reflected the observed relationship with human disturbance (Table 6). As such, least disturbed sites presented a trend towards high proportion of native metrics and low proportion of non-native species, whilst disturbed sites showed an opposite trend along the human pressure gradient. Accordingly, Alg, Cbx, Mos, Vas and Mtg should present higher fish assemblages integrity over the study period than the other sites, particularly Gar, Pec, Sdg, Saf and Val.

Mean similarities of fish metrics in sampled sites followed the pattern already observed for fish assemblages composition, though with higher values. Furthermore, metrics similarities tended to present higher differences between least disturbed and disturbed sites than similarities of fish composition. As for fish composition, fish metrics did not present significant correlations with species richness and total fish density $(\operatorname{adj} P>0.05)$.

\subsection{Relationships between fish assemblages variability, human pressure and hydrological variability}

Variability in fish assemblages was associated to human pressure and hydrological variability. Fish composition similarities showed significant correlations with altitude $(r=0.64$; $\operatorname{adj} P<0.05)$, annual rainfall $(r=0.61$; adj $P<0.05)$ and $C V$ of current velocity $(r=-0.51$; adj $P<0.05)$, but also with total pressure $(r=-0.66$; corrected $P<0.01)$, riparian degradation $(r=-0.59$; adj $P<0.05)$, sediment load $(r=-0.7$; adj $P<0.05)$ and organic/nutrient enrichment $(r=-0.5$; adj $P<0.05)$ (Table 7). Likewise, fish metrics similarities revealed significant correlations with altitude $(r=0.69$; adj $P<0.01)$, annual rainfall $(r=0.58$; adj $P<0.05), C V$ of annual rainfall $(r=-0.53$; adj $P<0.05)$, total pressure $(r=-0.72$; adj $P<0.01)$, land use $(r=-0.59$; adj $P<0.05)$, riparian degradation $(r=-0.62$; adj $P<0.01)$, sediment load $(r=-0.76$; adj $P<0.01)$ and organic/nutrient input $(r=-0.50$; adj $P<0.05)$ (Table 7$)$. On the other hand, assemblage persistence was only dependent on altitude $(r=0.71 ; \operatorname{adj} P<0.01)$ and annual rainfall $(r=0.60$; $\operatorname{adj} P<0.05)$ of sites. Despite the absence of significant results, a trend towards lower values was observed in most degraded sites.

However, total human pressure was also related to hydrological variability, showing significant correlations with annual rainfall $(r=-0.61 ; \operatorname{adj} P<0.05)$ and $\mathrm{CV}$ of annual rainfall $(r=0.59$; adj $P<0.05)$. Moreover, sediment load was related with the $\mathrm{CV}$ of annual rainfall $(r=0.72$; adj $P<0.01)$ and nutrient/organic enrichment decreased with the relative frequency of wetter years $(r=-0.64$; adj $P<0.05)$ and increased with the relative frequency of dryer years $(r=0.64$; adj $P<0.05)$ and cumulative rainfall deficit $(r=0.61 ; \operatorname{adj} P<0.05)$.

RDA results were in accordance with the observed correlations, further contributing to the general interpretation of major influences in assemblages variability and possible changes in ecological integrity. The first two axes $\left(\lambda_{1}=0.71 ; \lambda_{2}=0.07\right)$ accounted for $78 \%$ of the total variance in fish assemblages variability (considering both composition and structural and functional features) and nine significant $(P<0.05)$ variables were included in the ordination model. According to canonical coefficients and inter-set correlations, axis 1 was mainly defined by annual rainfall $(r=-0.76)$ and total human pressure $(r=0.70)$, and to a less extent by $\mathrm{CV}$ of current 
Table 7

Most relevant correlations $(|r| \geq 0.5$; adj $P<0.05)$ between fish assemblages variability (fish composition similarities, fish metrics similarities and assemblage persistence) and hydrological and anthropogenic variables.

\begin{tabular}{lll}
\hline Variables(hydrological and anthropogenic) & Correlations & \\
\cline { 2 - 3 } & Fish composition similarities & Fish metrics similarities \\
\hline Altitude & $r=0.64 ; P<0.05$ & $r=0.69 ; P<0.01$ \\
Annual rainfall & $r=0.61 ; P<0.05$ & $r=0.58 ; P<0.05$ \\
CV of annual rainfall & n.s. & $r=-0.53 ; P<0.05$ \\
CV of current velocity & $r=-0.51 ; P<0.05$ & n.s. \\
Total human pressure & $r=-0.66 ; P<0.01$ & $r=-0.72 ; P<0.01$ \\
Land use & n.s. & $r=-0.59 ; P<0.05$ \\
Riparian degradation & $r=-0.59 ; P<0.05$ & $r=-0.62 ; P<0.01$ \\
Sediment load & $r=-0.70 ; P<0.05$ & $r=-0.76 ; P<0.01$ \\
Organic/nutrient load & $r=-0.50 ; P<0.05$ & $r=0.50 ; P<0.05$ \\
\hline
\end{tabular}

velocity $(r=0.54)$ and $\mathrm{CV}$ of annual rainfall $(r=0.41)$, while axis 2 was more related to the increase in human pressure $(r=0.63)$.

Ordination diagram (biplot of sites $\times$ human pressure and hydrological variables) (Fig. 5) showed a good spatial dispersion of sites, especially along the first axis. Least disturbed sites (Alg, $\mathrm{Cbx}$, Mos and Vas) showed the highest fish assemblages stability and were mainly associated to high annual rainfall and cumulative surplus. On the contrary, most disturbed sites, especially Gar, Sdg, Saf and Pec, experienced meaningful changes in fish assemblages and simultaneously suffered the influence of high hydrological variability represented by $\mathrm{CV}$ of annual rainfall and habitat disturbance ( $\mathrm{CV}$ of current velocity and substrate). Cumulative rainfall deficit was one of the least important variables. However, this variable was more associated to assemblages changes in the most disturbed sites, even though high values have been also registered in least disturbed ones.

\section{Discussion}

Under the need for developing reliable biological indicators based on fish assemblages in a hydrologically variable environment as Mediterranean climate streams, this study analysed the

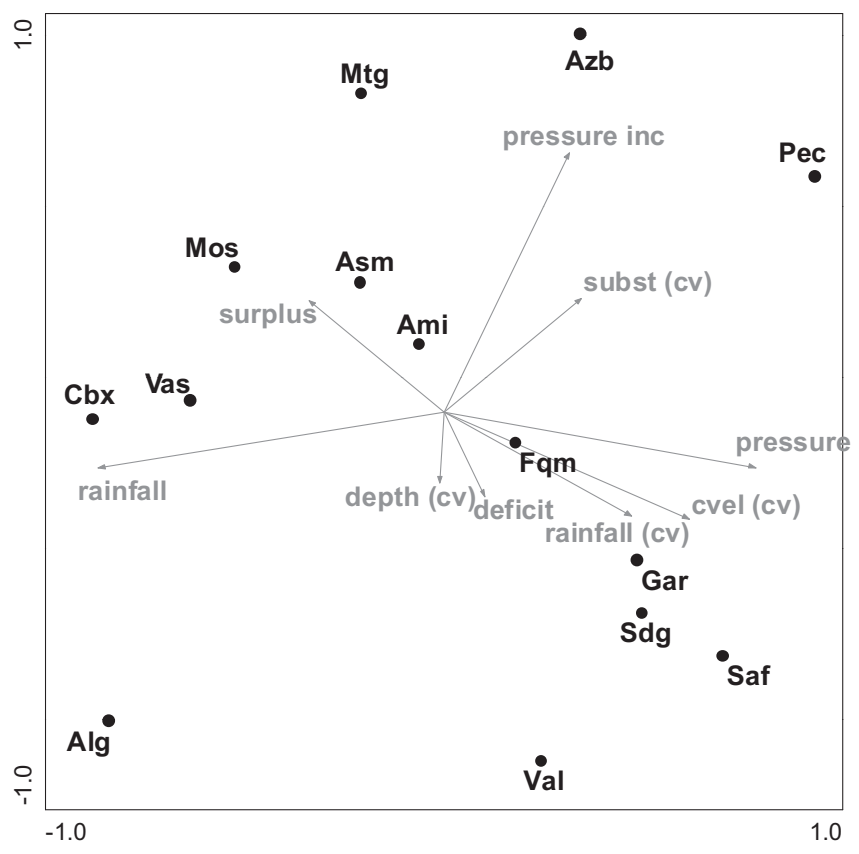

Fig. 5. Ordination diagram of Redundancy Analysis (RDA) between fish assemblages variability (Bray-Curtis similarities of sites along the years using fish composition and metrics), human pressure variables and hydrological variables. role of hydrological variability on the responses of fish assemblages to human disturbance in small intermittent streams.

In this context, spatial and inter-annual variability of fish assemblages was analysed based on relative abundance of fish species and structural and functional assemblage attributes (i.e. fish metrics). Fish assemblage attributes, which respond to anthropogenic disturbances but exhibit low natural temporal variability, are potentially the most sensitive indicators of human pressures to use in bioassessment (Paller, 2002). Seven metrics fulfilled those criteria and were thus selected to indicate possible changes in fish assembles integrity in each site: relative abundance of native species, relative abundance of native insectivorous species, relative abundance of native eurytopic species, relative abundance of native water column species, relative abundance of native lithophilic species, relative abundance of species with intermediate tolerance and relative number of exotic species. These metrics are then the most appropriate to include in a possible multimetric index based on fish fauna in small intermittent Mediterranean streams.

High variability of fish assemblages was mainly associated with the human-induced disturbance, particularly nutrient/organic load and sediment load. Both correlations and RDA results showed strong associations of Bray-Curtis similarity coefficients based on fish composition and metrics with human pressure variables. Diffuse pollution from agriculture is possibly the major human impact on the aquatic systems of southern Portugal, though livestock may have an important contribution to the organic loading. The absence of fences along the streams is very common, allowing cattle to invade the streams, often with destruction of riparian vegetation, factors that together lead to an increase in water eutrophication and ecosystem degradation (e.g. Vidon et al., 2008).

Fish assemblages variability was also related to hydrological variability, mainly expressed by $\mathrm{CV}$ of mean annual rainfall and alterations in habitat conditions following hydrological disturbances, particularly current velocity and substrate type. These results agree with previous studies on Mediterranean-type streams, presenting a wide inter-annual variation on fish assemblages associated to the typical hydrological fluctuations observed (Filipe et al., 2002; Magalhães et al., 2002a, 2007; Bernardo et al., 2003; Clavero et al., 2005; Mesquita et al., 2006; Ferreira et al., 2007). In least disturbed sites, despite the natural disturbances caused by inter-annual rainfall variations (including drought and flood events), long-term assemblage stability seems to be maintained. This was further confirmed by time lag regression and MDS analyses, as all least disturbed sites showed cyclic temporal patterns of changes in fish assemblages that underpin the existence of a drift-and-recovery pattern and a high resilience to natural disturbances (Magalhães et al., 2007). On the contrary, in disturbed sites, a directional trend pattern was observed, reflecting a decrease on the resistance and resilience of fish assemblages. In moderate disturbance conditions, no evident trend in fish assemblages changes was observed. The highly variable floods and drying events 


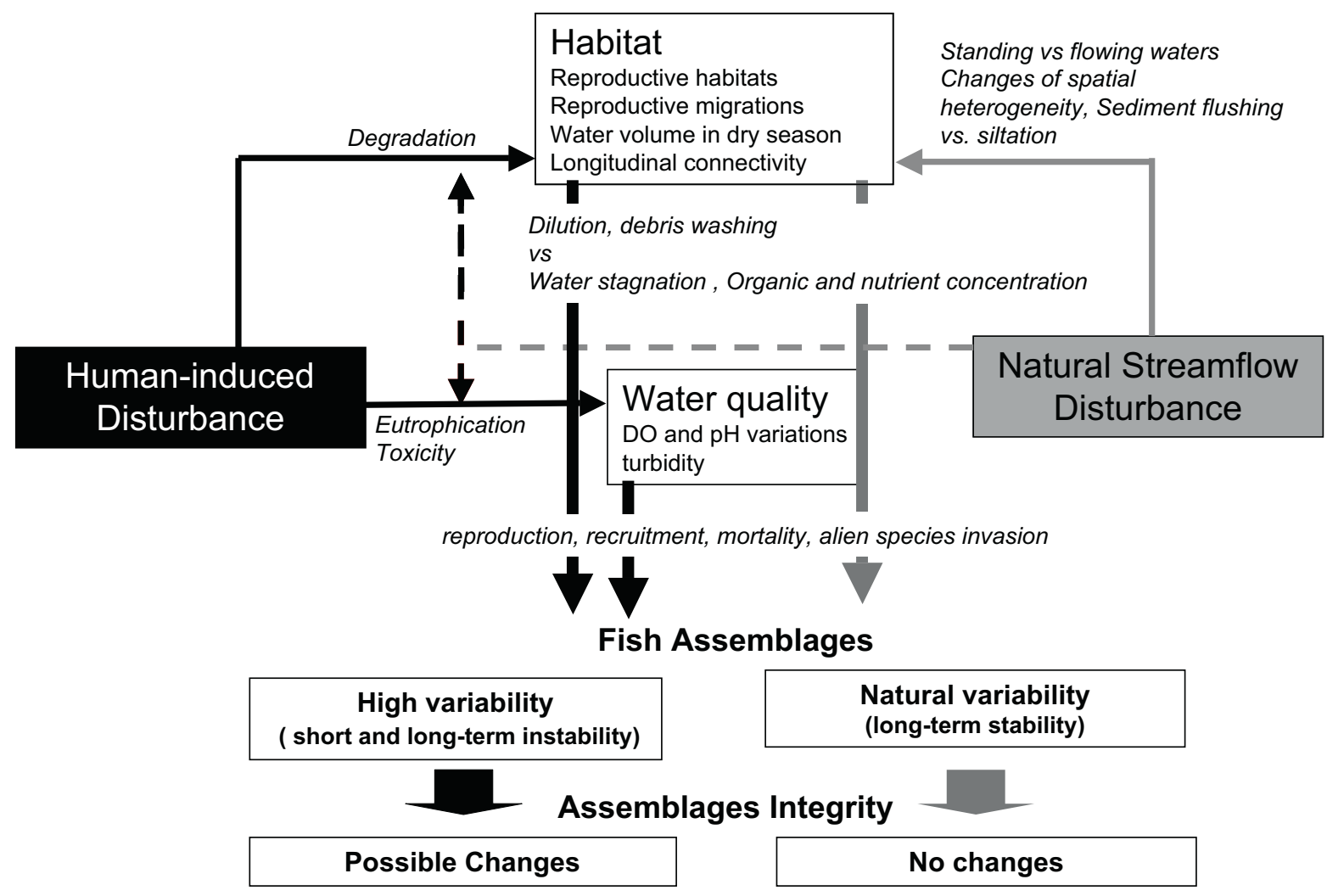

Fig. 6. Potential anthropogenic and hydrological mechanisms determining variation in fish assemblages.

in Mediterranean streams may have acted as selective environmental filters over very long time scales, thereby reducing the subset of species to those evolutionarily adapted to cope with the prevailing harsh environmental patterns (sensu Poff, 1997). On the contrary, disturbed sites presented much higher variability of fish composition and metrics, and directional temporal changes, hence a short and long-term instability possibly entailing changes in assemblages integrity. Similar results were found in other studies (e.g. Karr et al., 1987; Schlosser, 1990; Taylor et al., 1996; Paller, 2002) showing that fish assemblages exhibit higher temporal variability in disturbed environments.

In dryer years, low flow conditions directly affect the availability of and access to habitats, namely the reproductive ones, and, decreasing the water volume and wetted area, affect to some extent the life of fish, as well. As a result, reproduction and recruitment of the native fish are negatively affected and susceptibility to predation increases caused by confinement in smaller water bodies. For non-native species with benthic affinities, e.g. centrarchids, carp, or mosquitofish, stream conditions in dryer years become more suitable. But in human disturbed systems, especially in nutrient/organic enriched streams, during dry periods the aquatic biota face additional pressures. Low flow causes the intensification of eutrophication, as no washing out of finer and organic sediments and no dilution of nutrients and biomass take place and slower running waters are more favourable to primary production. Under these circumstances, the fish assemblages are subject to the natural hydrological disturbance and to its consequences on the water quality level, as well.

In the least disturbed sites, fish assemblages have to cope with the habitat changes caused by low flows and subsequently recover, which causes the observed cyclic pattern (alternating some loss of integrity and recovery). In the more disturbed sites, low flow conditions enhance the pressures exerted upon fish assemblages and no similar recovery is observed, originating a quite different pattern of response over time.
In this study neither the number of species nor the total fish density were shown to influence fish assemblages variability, leading to possible confounding results, as sites with higher species richness and abundance are likely to be less susceptible to environmental disturbances than sites with impoverished fish fauna, which are more prone to local extinctions (Tilman et al., 1998).

Along the study years, most sampled streams were subjected to an increase in human pressure, especially those located in streams nearby more populated areas. On the contrary, streams located at higher altitudes, in isolated areas with limited or difficult access, suffered the lowest increase in human disturbance and maintained least disturbed abiotic classification over the study period. This fact was determinant in the observed negative relation between human pressure and altitude, and consequently with total annual rainfall, which normally present high values in altitude areas. Therefore, the existence of a landscape gradient in fish assemblages variability defined by altitude actually reflects a prevailing human pressure gradient. Regarding other possible confounding landscape factors in interpreting the importance of human pressure and hydrological variability in fish assemblages variability, results also did not show any direct influence of drainage area (Horwitz, 1978; Schlosser, 1982).

Considering that inter-annual hydrological variability tended to be low in higher altitude streams, the discussed increase in anthropogenic disturbance observed in many lowland sites was also partially responsible for the positive relation observed between total human pressure and hydrological variability. Nevertheless, results also suggest that hydrological variability may aggravate the impact of human pressures (and to a certain extent their evaluation) in fish assemblages, as reflected by the relations between sediment load and the $\mathrm{CV}$ of annual rainfall, and also between nutrient/organic load and the relative frequency of wetter and dryer years and cumulative rainfall deficit.

Accordingly, in sites with high annual rainfall and lower interannual hydrological variability high flows are more frequent, 
leading to habitat rearrangement and flush out of fine sediments and organic material. In fact, the mentioned negative correlation between the relative frequency of wetter years and organic/nutrient pressure is related to the fact that high flow conditions may promote nutrient dilution, improving the water quality and reducing the impact of organic/nutrient load on the biota. Moreover, wetter years favour the reproduction of native species (Bernardo et al., 2003; Hill et al., 1991) as well as promoting postsummer recolonizations and spawning migrations up the river systems (Bernardo and Alves, 1999; Magalhães et al., 2002b; Ilhéu, 2004). Several studies reported increased recruitment of native juveniles following flow disturbance, causing rapid recovery of fish assemblages (e.g. Bohnsack, 1983; Closs and Lake, 1996; LobónCerviá, 1996).

On the contrary, in sites with lower annual rainfall and high hydrological variability, the frequent and cumulative absence of floods can act at two levels (Bernardo et al., 2003): (i) decreasing habitat complexity and diversity, promoting siltation and degradation of the water quality, negatively affecting the native fish habitats including the reproductive ones and those required for early life-history stages; (ii) favouring conditions for the recruitment and no flush out of the alien limnophilic species, thus increasing the pressure on the native species through competition and predation.

Results from the sites where abiotic classification changed during the study period (Mtg, Asm, Ami, Azb and Fqm) further reinforced these conclusions. In fact, changes in fish assemblages were lower when hydrological variability was also lower (Asm and $\mathrm{Mtg}$ ), despite the more or less similar increase in human pressure registered in these sites.

In sum, results suggest that hydrological variability can act jointly with anthropogenic disturbances, producing both direct and indirect effects on fish assemblages in small intermittent streams (Fig. 6). In human disturbed situations, high hydrological variability (especially if it entails high frequency of dryer years and meaningful cumulative water deficit) may affect the impact of the human pressures both on habitat and on water quality, with significant and consistent variations of fish assemblages composition and integrity that may influence the ecological assessment. Indeed, in sites with variable hydrological regimes and disturbance histories, substantially different conclusions from bioassessment of a site can be obtained from different years, even if data was collected identically on each sampling occasion and no change in human disturbance was registered (Wilcox et al., 2002).

The synergetic effects of hydrological variability and human pressures on fish assemblages, acquires particular importance under a climatic change scenario (see Santos and Miranda, 2006) that foresees significant impacts not only towards an increase in temperature, but also towards reductions in rainfall and increases in inter-annual flow variability in Mediterranean streams. Consequently, these aquatic ecosystems are likely to be highly vulnerable to long-term changes in hydrologic regime in the future. The selection of metrics for the fish multi-metric indexes should avoid possible bias related to metrics, which might respond to natural hydrological variations.

\section{Conclusions}

High hydrological variability may affect fish assemblages composition, but native fish species seem to exhibit high resilience to natural disturbance when hydrological and habitat conditions resemble the pre-disturbed state. Despite the relatively small number of sites analysed, this study contributes to highlight the importance of assessing temporal variability on stream biomonitoring programs. This approach makes possible to distinguish substantive ecological changes from natural fluctuations of fish assemblage structure. In this study, the fish metrics selected to assess changes in assemblages integrity are based on the relative abundance of native species (insectivorous species, eurytopic species, water column species, native lithophilic species), relative abundance of species with intermediate tolerance and relative number of exotic species. These metrics are the most appropriate for inclusion in a multimetric index to be developed for these streams because they respond to anthropogenic disturbances but exhibit low natural temporal variability. Nevertheless, reevaluation of this issue with larger data sets from different river types and longer time series including extreme natural events would help to improve and expand the present results. Moreover, a correction of class boundaries for the developed biotic indexes may also be a possible solution in order to improve the assessment accuracy in small Mediterranean climate streams.

\section{Acknowledgements}

This study gathered data collected under several different programmes: (i) assessment of the ecological flow in Guadana river basin, partially funded by the National Water Agency (INAG, Instituto Nacional da Água); (ii) the implementation of the Water Framework Directive, partially funded by the National Water agency; and (iii) climate change and fish communities of Mediterranean-type streams - potential impact on the biointegrity and implications on the ecological status assessment, funded by FCT (Fundação para a Ciência e Tecnologia). P. Matono was supported by a grant from FCT and later by a grant from IIFA (Instituto de Investigação e Formação Avançada, Universidade de Évora). Special thanks are due to all the colleagues and volunteers from the University of Évora who collaborated in the fieldwork along the study years. We also thank Eng. Manuela Correia for helping with the production of the study area map. The National Forest Authority provided the necessary fishing permits.

\section{References}

Aarts, B.G.W., Van den Brink, F.W.B., Nienhuis, P.H., 2004. Habitat loss as the main cause of slow recovery of fish faunas of regulated large rivers in Europe: the transversal floodplain gradient. River Res. Appl. 20, 3-23.

Almaça, C., 1995. Freshwater fish and their conservation in Portugal. Biol. Conserv. 72, 125-127.

ARHA, 2011. Plano de Gestão das Bacias hidrográficas integradas nas Regiões Hidrográficas 6 e 7. Ministério do Ambiente, do Ordenamento do Território e do Desenvolvimento Regional. Administração da Região Hidrográfica do Alentejo, Évora.

Arthington, A.H., Bunn, S.E., Poff, N.L., Naiman, R., 2006. The challenge of providing environmental flow rules to sustain river ecosystems. Ecol. Appl. 16, 1311-1318.

Benejam, L., Angermeier, P., Garcia-Berthou, A., Munne, E., 2009. Assessing effects of water abstraction on fish assemblages in Mediterranean streams. Freshw. Biol. $55,628-642$.

Bernardo, J.M., Alves, M.H., 1999. New perspectives for ecological flow determination in semi-arid regions: a preliminary approach. Regul. River 15, 221-229.

Bernardo, J.M., Ilhéu, M., Matono, P., Costa, A.M., 2003. Interannual variation of fish assemblage structure in a Mediterranean river: implications of streamflow on the dominance of native or exotic species. River Res. Appl. 19, 1-12.

Bohnsack, J.A., 1983. Resiliency of reef fish communities in the Florida Keys following a January 1977 hypothermal fish kill. Environ. Biol. Fish. 9, 41-53.

Cabral, M.J.(coord.), Almeida, J., Almeida, P.R., Dellinger, T.R., Ferrand de Almeida, N., Oliveira, M.E., Palmeirim, J.M., Queiroz, A.I., Rogado, L., Santos-Reis, M. (Eds.), 2005. Livro Vermelho dos Vertebrados de Portugal. Instituto da Conservação da Natureza, Lisboa.

Caetano, M., Nunes, V., Nunes, A., 2009. CORINE Land Cover 2006 for Continental Portugal. Instituto Geográfico Português, Lisboa.

CEN, 2003. Water Quality - Sampling of Fish with Electricity. European Standard EN 14011:2003. European Committee for Standardization, Brussels.

Clarke, K.R., Warwick, R.M., 1994. Change in Marine Communities: An Approach to Statistical Analysis and Interpretation. Plymouth Marine Laboratory, Plymouth, UK.

Clarke, K.R., Gorley, R.N., 2006. Primer v6: User Manual/Tutorial. Plymouth Marine Laboratory, Plymouth, UK. 
Clavero, M., Blanco-Garrido, F. Zamoral, L., Prenda, J., 2005. Size-related and diel variations in microhabitat use of three endangered small fishes in a Mediterranean Coastal stream. J. Fish Biol. 67, 72-85.

Clesceri, L.S., Greenberg, A.E., Eaton, A.D. (Eds.), 1998. Standard Methods for the Examination of Water and Wastewater. , 20th ed. American Public Health Association, American Water Works Association, Water Environmental Federation, Washington, DC

Closs, G.P., Lake, P.S., 1996. Drought differential mortality and the coexistence of a native and an introduced fish species in a southeast Australian intermittent stream. Environ. Biol. Fish. 47, 17-26.

Collins, S.L., 2000. Disturbance frequency and community stability in native tallgrass prairie. Am. Nat. 150, 311-325.

Cummins, K.W., Spengler, G.L., 1978. Stream ecosystems. Water Spectrum 10, 1-9.

Daveau, S., 1977. Répartition et rythme des précipitations au Portugal, Memórias. C.E.G., Lisbon.

Eby, L.A., Fagan, W.F., Minckley, W.L., 2003. Variability and dynamics of a desert stream community. Ecol. Appl. 13, 1566-1579.

European Commission, 2000. Directive 2000/60/EC. Establishing a Framework for Community Action in the Field of Water Policy. European Commission PE-CONS 3639/1/100, Luxembourg, Available from: http://ec.europa.eu/ environment/water/water-framework/index_en.html.

FAME, 2004. Development, Evaluation \& Implementation of a Standardised Fish-based Assessment Method for the Ecological Status of European Rivers-A Contribution to the Water Framework Directive. Final Report, scientific achievements (Sections 5 \& 6) (Co-ordinator: Stefan Schmutz) Institute for Hydrobiology and Aquatic Ecosystem Management, University of Natural Resources and Applied Life Sciences, Vienna. Available from: http://fame.boku.ac.at.

Ferreira, T., Caiola, N., Casals, F., Cortes, R., Economous, A., Garcia-Jalon, D., Ilhéu, M., Martinez-Capel, F., Oliveira, J., Pont, D., Prenda, J., Rogers, C., De Sostoa, A., Zogaris, S., 2007. Ecological traits of fish assemblages from Mediterranean Europe and its implications when assessing human pressure. Fish. Manage. Ecol. 14, 473-481.

Filipe, A.F., Cowx, I.G., Collares-Pereira, M.J., 2002. Spatial modelling of freshwater fish in semi-arid river systems: a tool for conservation. River Res. Appl. 18 123-136.

Freeman, M.C., Zachary, H.B., Bovee, K.D., Irwnin, E., 2001. Flow and habitat effects on juvenile fish abundance in natural and altered flow regimes. Ecol. Appl. 11, 179-190.

Gasith, A., Resh, V.H., 1999. Streams in Mediterranean climate regions: abiotic influences and biotic responses to predictable seasonal events. Annu. Rev. Ecol. Syst. 30, 51-81.

Gehrke, P.C., Astles, K.L., Harris, J.H., 1999. Within-catchment effects of flow alteration on fish assemblages in the Hawkesbury-Napean River system. Regul. River 15, 181-198.

Gehrke, P.C., Harris, J.H., 2001. Regional-scale effects of flow regulation on lowland riverine fish communities in New South Wales, Australia. River Res. Appl. 17, 369-391.

Giller, P.S., Malmqvist, B., 1998. The Biology of Streams and Rivers. Oxford University Press, New York.

Gorman, O.T., Karr, J.R., 1978. Habitat structure and stream fish communities. Ecology $59,507-515$.

Grossman, G.D., Dowd, J.F., Crawford, M., 1990. Assemblage stability in stream fishes: a review. Environ. Manage. 14, 661-671.

Hermoso, V., Clavero, M., 2011. Threatening processes and conservation management of endemic freshwater fish in the Mediterranean basin: a review. Mar. Freshwater Res. 62, 244-254.

Hill, M.T., Platts, W.S., Beschta, R.L., 1991. Ecological and geomorphological concepts for instream and out-of-channel flow requirements. Rivers 2, 198-210.

Holzer S., 2008. European fish species: taxa and guilds classification regarding fishbased assessment methods. PhD Thesis. Universitat fur Bodenkultur.

Horwitz, R.J., 1978. Temporal variability patterns and the distributional patterns of stream fishes. Ecol. Monogr. 48, 307-321.

Ilhéu, M., 2004. Patterns of habitat use by freshwater fishes in Mediterranean rivers. $\mathrm{PhD}$ thesis. University of Évora, Évora.

INAG, I.P., 2008. Manual for Biological Assessment of Water Quality in Rivers According to Water Framework Directive. Sampling and Analysis Protocol for Fish Fauna [In Portuguese]. Ministério do Ambiente, do Ordenamento do Território e do Desenvolvimento Regional. Instituto da Água, Lisboa, Available from: http://dqa.inag.pt.

Jongman, R.H.G., ter Braak, C.J.F., van Tongeren, O.F.R., 1987. Data Analysis in Community and Landscape Ecology. Pudoc, Wageningen, The Netherlands.

Karr, J.R., Yant, P.R., Fausch, K.D., 1987. Spatial and temporal variability of the index of biotic integrity in three Midwestern streams. Trans. Am. Fish. Soc. 116 $1-11$.

Laraus, J., 2004. The problems of sustainable water use in the Mediterranean and research requirements for agriculture. Ann. Appl. Biol. 144 259-272.

Legendre, P., Legendre, L., 1998. Numerical Ecology, 2nd ed. Elsevier, Amsterdam.

Lobón-Cerviá, J., 1996. Response of a stream fish assemblage to a severe spate in Northern Spain. Trans. Am. Fish. Soc. 125, 913-919.

Lytle, D.H., Poff, N.L., 2004. Adaptation to natural flow regimes. Trends Ecol. Evol. 19, 94-100.

Magalhães, M.F., Batalha, D.C., Collares-Pereira, M.J., 2002a. Gradients in stream fish assemblages across a Mediterranean landscape: contributions of environmental factors and spatial structure. Freshw. Biol. 47, 1015-1031.
Magalhães, M.F., Beja, P. Canas, C. Collares-Pereira, M. 2002b. Functional heterogeneity of dry-season fish refugia across a Mediterranean catchment: the role of habitat and predation. Freshw. Biol. 47, 1919-1934.

Magalhães, M.F., Beja, P., Schlosser, I.J., Collares-Pereira, M.J., 2007. Effects of multiyear droughts on fish assemblages of seasonally drying Mediterranean streams. Freshw. Biol. 52, 1494-1510.

Magalhães, M.F., Ramalho, C.E., Collares-Pereira, M.J., 2008. Assessing biotic integrity in a Mediterranean watershed: development and evaluation of a fish-based index. Fish. Manage. Ecol. 15, 273-289.

Matthews, W.J., Marsh-Matthews, E., 2003. Effects of drought on fish across axes of space, time and ecological complexity. Freshw. Biol. 48, 1232-1253.

Mesquita, N.M., Coelho, M., Magalhães, M.F., 2006. Spatial variation in fish assemblages across small Mediterranean drainages: effects of habitat and landscape context. Environ. Biol. Fish. 77, 105-120.

Morais, P., 2008. Review on the major ecosystem impacts caused by damming and watershed development in an Iberian basin (SW-Europe): focus on the Guadiana estuary. Ann. Limnol.: Int. J. Lim. 44, 105-117.

Murchie, K.J., Hair, k.P.E., Pullen, E., Redpath, D., Stephens, R., Cooke, J., 2008. Fish response to modified flow regimes in regulated rivers: research methods, effects and opportunities. River Res. Appl. 24, 197-217.

Oberdorff, T., Hugueny, B., Vigeron, T., 2001. Is assemblage variability related to environmental variability? An answer to riverine fish. Oikos 93, 419-428.

Oberdorff, T., Pont, D., Hugueny, B., Porcher, J.P., 2002. Development and validation of a fish-based index (FBI) for the assessment of 'river health' in France. Freshw. Biol. 47, 1720-1734

Orth, D.J., Maughan, O.E., 1982. Evaluation of the incremental methodology for recommending instream flow for fishes. Trans. Am. Fish. Soc. 111, 413-445.

Paller, M.H., 2002. Temporal variability in fish assemblages from disturbed and undisturbed streams. J. Aquat. Ecosyst. Stress Recov. 9, 149-158.

Pegg, M.A., Pierce, C.L., 2002. Fish community structure in the Missouri and lower Yellowstone rivers in relation to flow characteristics. Hydrobiologia 479 155-167.

Peña, J., Bonet, A., Bellot, J., Sánchez, J.R., Eisenhuth, D., Hallett, S., Aledo, A., 2007. Driving forces of land-use change in a cultural landscape of Spain. In: Koomen, E. Stillwell, J., Bakema, A., Scholten, H.J. (Eds.), Modelling Land-Use Change Progress and Applications. Springer, Netherlands, pp. 97-115.

Pereira, L.S., Louro, V., Rosário, L., Almeida, A., 2006. Desertification, territory and people, a holistic approach in the Portuguese context. In: Kepner, W.G., Rubio, J.L., Mouat, D.A., Pedrazzini, F. (Eds.), Desertification in the Mediterranean Region: A Security Issue. NATO Sc.Com., AK/Nato Publishing Unit, SpringerVerlag, Dordrecht, pp. 269-289.

Poff, N.L., 1997. Landscape filters and species traits: towards mechanistic understanding and prediction in stream ecology. J. N. Am. Benthol. Soc. 16, 391-409.

Poff, N.L., Allan, J.D., Bain, M.B., Karr, J.R., Prestegaard, K.I., Richter, B.D., Sparks, R.E., Stromberg, J.C., 1997. The natural flow regime: a paradigm for river conservation and restoration. Bioscience 47, 769-784.

Pont, D., Hugueny, B., Beier, U., Goffaux, D., Melcher, A., Noble, R., Rogers, C., Roset, N., Schmutz, S., 2006. Assessing river biotic condition at a continental scale: a European approach using functional metrics and fish assemblages. J. Appl. Ecol $43,70-80$.

Resh, V.H., Brown, A.V., Covich, A.P., Gurtz, M.E., Li, H.W., Minshall, G.W., Reice, S.R., Sheldon, A.L., Wallace, J.B., Wissmar, R., 1988. The role of disturbance in stream ecology. J. N. Am. Benthol. Soc. 7, 433-455.

Sagawa, S., Kayaba, Y., Takashi, T., 2007. Changes in fish assemblage structure with variability of flow in two different channel types. Landsc. Ecol. Eng. 3, 119-130.

Santos, J.M., Godinho, F., Ferreira, M.T., Cortes, R., 2004. The organisation of fish assemblages in the regulated Lima basin, Northern Portugal. Limnologica 34, 224-235.

Santos, F.D., Miranda, P., 2006. Alterações climáticas em Portugal: Cenáros, Impactos e Medidas de Adapatação. Gradiva, Lisboa.

Schlosser, I.J., 1982. Fish community structure and function along two habitat gradients in a headwater stream. Ecol. Monogr. 52, 395-414.

Schlosser, I.J., 1990. Environmental variation, life history attributes, and community structure in stream fishes: implications for environmental management and assessment. Environ. Manage. 14, 621-628.

Siegel, S., Castellan, N.J., 1988. Nonparametrics Statistics for the Behavioural Sciences, 2nd ed. McGraw-Hill International, New York.

Smith, K.G., Darwall, W.R.T., 2006. The Status and Distribution of Freshwater Fish Endemic to the Mediterranean Basin. IUCN - The World Conservation Union, Switzerland/Cambridge, UK.

SNIRH, Sistema Nacional de Informação de Recursos Hídricos. Available from: http://snirh.pt.

StatSoft Inc., 2001. Statistica (Data analysis software system), version 6.

Symeonakis, E., Calvo-Cases, A., Arnau-Rosalen, E., 2007. Land use change and land degradation in south eastern Mediterranean Spain. Environ. Manage. 40, 80-94.

Taylor, C.M., Winston, M.R., Matthews, W.J., 1996. Temporal variation in tributary and mainstream fish assemblages in a Great Plains stream system. Copeia 1996 280-289.

ter Braak, C.J.F., Smilauer, P., 1998. CANOCO Reference Manual and User's Guide to Canoco for Windows: Software for Canonical Community Ordination (Version 4.0). Microcomputer Power, Ithaca, NY.

ter Braak, C.J.F., Smilauer, P., 2002. CANOCO Reference Manual and CanoDraw for Windows User's Guide: Software for Canonical Community Ordination (Version 4.5). Microcomputer Power, Ithaca, NY. 
Tilman, D., Lehmaan, C.L., Bristow, C.E., 1998. Diversity-stability relationship: statistical inevitability or ecological consequence? Am. Nat. 151, 277-282.

Vidon, P., Campbell, M.A., Gray, M., 2008. Unrestricted cattle access to streams and water quality in till landscape of the Midwest. Agric. Water Manage. 95, 322-330.

Wilcox, D.A., Meeker, J.E., Hudson, P.L., Armitage, B.J., Black, M.G., Uzarski, D.G., 2002. Hydrological variability and the application of index of biotic integrity metrics to wetlands: a Great Lakes evaluation. Wetlands 22, 588-615.
Wright, S.P., 1992. Adjusted P-values for simultaneous inference. Biometrics 48, 1005-1013.

Xenopoulos, M.A., Lodge, D.M., 2006. Going with the flow: using species-discharge relationships to forecast losses in fish biodiversity. Ecology 87, 1907-1914.

Yevjevich, V., 1967. An objective approach to definitions and investigations of continental hydrologic droughts. Colorado State Univ. Hydrol. Paper 23, 1-18. 